\title{
UNA MIRADA A LA DOCTRINA DE LA CAUSA Y SUS DISTINTAS VERSIONES EN EL CÓDIGO CIVIL CHILENO
}

\section{JOSÉ RIVERA RESTREPO*}

RESUMEN: El problema de la causa ha sido una constante del pensamiento filosófico y jurídico. Desde Parménides han sido varios los pensadores que han pretendido esbozar algunas nociones en torno al tema, así, por ejemplo, es posible mencionar a Aristóteles, Kant, Hume, Hegel entre otros. Se debe indicar que en el campo de la filosofía, el tema no es pacífico, dando lugar a variadas disputas intelectuales. Para la desdicha de los juristas, esa complejidad se ha trasladado al ámbito jurídico. En esta investigación, se enunciarán los aspectos generales más relevantes en torno a la doctrina de la causa, pretendiéndose responder la siguiente pregunta: ¿se justifica en nuestro Derecho la noción de causa?

PALABRAS CLAVE: Causa - abstracción - contrato - negocio jurídico acto jurídico.

\section{A LOOK AT THE CAUSE DOCTRINE AND IT'S DIFFERENT VERSIONS IN THE CHILEAN CIVIL CODE}

ABSTRACT: The problem of the cause has been a constant topic of philosophical and legal matters. From Parmenides, there have been several thinkers who have tried to outline some ideas on the subject, so for example, it is possible to mention Aristotle, Kant, Hume, Hegel,

A modo de advertencia, se debe indicar que este ensayo se enmarca dentro de una investigación sobre la causa que consta de tres partes: el primero trata acerca De los aspectos generales en torno a la teoría de la causa, y fue publicado en la Revista Ars Noni et Aequi, No 7, Segundo Semestre, Facultad de Derecho, Universidad Bernardo O'Higgins, agosto de 2010; el segundo aparecerá en el No 4 de la Revista del Magister y Doctorado en Derecho, Escuela de Graduados, Facultad de Derecho, Universidad de Chile, bajo el nombre: De la causa en el Derecho comparado. Por ello, en el presente trabajo solo se abordará la teoría de la causa en nuestro país, con algunas notas de Derecho francés sobre la materia.

** Licenciado en Ciencias Jurídicas y Sociales por la Universidad de Chile y Magíster en Derecho, con mención en Derecho Privado por la misma Universidad. Investigador del Centro de Investigaciones Jurídicas de la Universidad Central de Chile y Profesor de Derecho Civil en las Universidades de Chile, Central, de los Andes y Alberto Hurtado. Seleccionado por BecasChile 2010 y aceptado en el Programa de Formación Doctoral en Derecho en la Universidad Complutense de Madrid. Correo electrónico: rivera_lex@yahoo.es

Fecha de recepción: 22 de diciembre de 2010.

Fecha de aceptación: 18 de agosto de 2011. 
among others. It should be noted that in the field of philosophy the subject is not peaceful, giving rise to various intellectual disputes. For the unhappiness of jurists, this complexity has been transferred to the legal field. In this research, it will be mentioned the most important general issues surrounding the cause doctrine, pretending to answer the following question: is it justified in our law the notion of cause?

KEY WORDS: Cause - abstraction - contract - business law - legal act.

\section{1) Planteamiento}

Para nadie es un misterio la notable influencia que la filosofía ha ejercido sobre las ciencias jurídicas. Así por ejemplo, la concepción romana sobre adquisición de los derechos reales, conforme a la cual es necesario de un título y un modo de adquirir, para que un derecho real ingrese al patrimonio de un sujeto de derecho, esta se sustentaría teóricamente en la obra de Aristóteles, para quien es necesaria la existencia de una "posibilidad" o "potencia" (título) y de una "realidad" (modo de adquirir el dominio), mediando entre ellas una relación de causalidad ${ }^{1,2}$.

En el ámbito del Derecho, los sistemas jurídicos exigen para la validez del contrato, la presencia de consentimiento, un objeto y la capacidad de los contratantes, no todos exigen la presencia del elemento causa. Como indica Morales: "A excepción de los países latinos y aquellos que se inspiraron de igual manera en el código de Napoleón, los derechos

1 Aristóteles señala que: "[...] En estrecha relación con lo anterior está la cuestión de si los elementos existen en potencia o de alguna otra manera. Pues, si existen de algún otro modo, habrá alguna otra cosa anterior a los principios (pues la potencia es anterior a aquella causa, y, lo que está en potencia, no todo llega a existir necesariamente de aquel modo). Pero, si los elementos están en potencia, cabe que ninguno de los entes exista; en efecto, está en potencia para existir incluso lo que aún no existe; pues se genera lo que no es, pero no se genera ninguna de las cosas que no están en potencia para ser [...]”. ARIstóteles (1970) Metafísica. Edición Trilingüe por Valentín García Yebra, Madrid. Editorial Gredos: p. 36.

2 Al respecto, vid. Aristóteles (1970) 36; Marías, Julián (1986) Historia de la Filosofía. Primera Reedición en Alianza Universidad Textos. Prólogo de Xavier Zubiri. Epílogo de José Ortega y Gasset, Madrid: Alianza Editorial, p. 69; Platón (1960) VII Diálogos. Filebos, Timaios y Kritias, Madrid: Imprenta Sáez, pp. 219-220; SAn Agustín de Hipona (2000) Las Confesiones. 2a Edición de Olegario García de la Fuente, Madrid: Ediciones Akal S. A., Libro X, Capítulo VI, pp. 240-241; San Agustín de Hipona (1793) La Ciudad de Dios. Traducción del latín al castellano por Joseph Cayetano Díaz de Beyral y Bermúdez, Madrid: Imprenta Real, Libro I, Capítulo XI, pp. 34 y ss.; 56 y ss.; Santo Tomás De Aquino (1990) III Suma Teológica. Prima Pars, Tratado de la Creación o Producción de todos los Seres por Dios, Q. 44, Sobre las criaturas en cuanto procedentes de Dios y sobre la primera causa de todos los seres, Introducción a las cuestiones 44 a 49 por José María Artola Barrenechea O.P., Madrid: Biblioteca de Autores Cristianos, p. 446. 
germánicos y escandinavos ignoran la figura, e incluso, en los trabajos emprendidos en Europa en vista de una armonización del derecho de los contratos, la causa es uno de los grandes ausentes. Ni los "Principios de derecho europeo" elaborados por la comisión Lando ni el "Anteproyecto de Código Europeo de Contratos", redactado por la Academia de Privatistas Europeos, mencionan en alguna de sus disposiciones el término causa"3.

Sin embargo, en nuestro ordenamiento jurídico, el artículo 1445 del Código Civil nos advierte que para que una persona se obligue a otra por un acto o declaración de voluntad es necesario "(40) que tenga una causa lícita". Esta norma nos señala por tanto, la necesidad de una causa. Pero, la pregunta que surge es: ¿se justifica la noción de "causa" en nuestro Código Civil? Ello, por cuanto la dogmática moderna, principalmente francesa, se ha preguntado por la necesidad del mantenimiento del instituto de la causa en el Código Civil francés, ya que el Derecho comunitario apunta en sentido inverso: dejar de lado la noción de causa y centrarse en el consentimiento de los negocios jurídicos.

En las líneas que siguen, me propongo otorgar algunas razones por las cuales, el instituto de la causa no solo debería ser mantenido en nuestro Ordenamiento Jurídico, sino que además, la jurisprudencia debería entenderlo en una nueva dimensión, distinguiendo la causa del contrato y la causa de la obligación: la primera debería ser entendida en sentido subjetivo, como el móvil que determina a las partes a contratar, es decir, como sinónimo de motivo, que lleva a los contratantes a celebrar el negocio jurídico; la segunda, en cambio, también llamada causa abstracta, se ajustaría perfectamente a los postulados tradiciones de la causa, ya que ella asume un carácter objetivo, atendiendo al tipo de negocio de que se trate.

Lo anterior serviría, según nuestra opinión, para cumplir con el verdadero fin que tiene el requisito causa: servir como elemento integrador de la ley, por ejemplo, en materia de competencia desleal, con el fin de salvar los vacíos que presenta la Ley No 20.169 sobre competencia desleal, con la finalidad de castigar los actos ilícitos basados en el abuso de la posición dominante en el mercado de ciertas empresas ${ }^{4}$. Además, la causa podría servir de fundamento para concretar el principio de abuso del derecho y la revisión judicial del contrato (lesión enorme y teoría de la imprevisión), es decir, la noción de causa no solo estaría presente al momen-

3 Morales Huertas, Margarita (2009) La renovación del concepto de causa en el Derecho francés. En Revista de Derecho Privado, Madrid, pp. 170.171.

4 Vid. Rivera Restrepo, José y Urdangarín Mahn, Jaime (2011) La imitación desleal por aprovechamiento de la reputación y del esfuerzo ajeno. En Revista de la Facultad de Derecho de la Universidad Jesuita Alberto Hurtado, paper aceptado por el Consejo de Redacción, en imprenta. 
to de la celebración del contrato, por el contrario, recorrería todo el iter contractual hasta la etapa de ejecución de las obligaciones nacidas de él.

Por razones de orden y con el fin de presentar el tema en cuestión, nos proponemos otorgar algunas notas apriorísticas en torno a los antecedentes históricos que tuvo presente el principal redactor del Código Civil chileno en esta materia, analizar en la segunda parte las normas del Código Civil en que se trata de la causa, refiriéndonos a su necesidad, expresión y requisitos, ¿qué es lo que requiere causa?, revisar el tipo de causa que consagra el Código de Bello y, por último, presentar algunos argumentos que apoyen la necesidad de mantener a la causa como requisito indispensable para la validez de todo acto jurídico.

Ahora bien, se ha dicho que en la doctrina de la causa se trata, en el fondo, de una contradicción entre la justicia y la injusticia, entre la letra fría de la ley y la realidad siempre original y cambiante. Como dice Capitant: La teoría de la causa "asegura la moralización del Derecho" 5.

Habiendo efectuado esta acotación preliminar y con el fin de precisar el objeto de nuestro estudio, podemos señalar como nuestra hipótesis de trabajo es siguiente: ¿La noción de causa se justifica en nuestro Derecho? En caso de responder afirmativamente a esta cuestión, surge una segunda pregunta: ¿La causa es un elemento necesario del contrato, de la obligación o de ambos? Y, por último, en caso de optar por la tercera alternativa, surge una pregunta final: ¿la causa constituye una noción dualista o es un concepto unitario? Sobre este punto, dice Guzmán Brito: "La curiosa anomalía presente en el articulado del código francés, consistente en anunciar una condition necesaria para la convention, y en terminar describiendo una condición de la obligation, se esparció en la legislación posterior"6. Y nuestro Código Civil no fue la excepción, pues él contiene disposiciones contradictorias en torno a dicha cuestión. En efecto, mientras el artículo 1445 dispone que: "Para que una persona se obligue a otra por un acto o declaración de voluntad es necesario: [...] $4^{\circ}$ que tenga una causa lícita [...]"; el artículo 1467 inciso $2^{\circ}$, primera parte, al definir la causa señala que: "Se entiende por causa el motivo que induce al acto o contrato". La pregunta que cabe hacerse es ¿cómo conciliamos dichas normas? o bien, ¿qué es lo que requiere causa, la obligación, el acto jurídico o ambos? Ahora bien, quizás podría contener el Código Civil dos especies de causa, aquella que justifica a la obligación, que podría asumir un rol objetivo, siendo la misma atendiendo al tipo de contrato de que se trate y, por otra parte, una causa subjetiva o impulsiva, que justificara por qué una parte se encuentra obligada para con otra. De concluirse lo anterior,

5 De Page, Henri (1957) L'obligation abstraite en Droit interne et en Droit comparé. Traducción de Janette Escobar, Bruselas: p. 8.

6 Guzmán Brito, Alejandro (2005) Acto, negocio, contrato y causa en la tradición del Derecho Europeo e iberoamericano. Primera edición. Navarra: Cizur Menor, p. 218. 
es decir, que no existe contradicción entre las normas precedentes, se demostraría una vez más la genialidad del maestro Bello, que se habría adelantado un siglo y medio a la actual discusión en esta materia. Siguiendo con el razonamiento anterior y, desde la perspectiva del tipo de causa que consagra el Código Civil chileno, procuraremos esbozar las opiniones que se han formulado sobre el tema, exponiendo los distintos argumentos que plantean los defensores de una y otra opinión, y sin pretender resolver esta polémica, señalar nuestra opinión sobre la cuestión, determinando la importancia de adherir a una u otra opinión. Es decir, intentaremos responder la siguiente pregunta: ¿La teoría de la causa consagrada en el Código Civil adhiere a los postulados modernos de las teorías objetiva, subjetiva o ambas?

\section{2) ANTECEDENTES HISTÓRICOS}

Cabe agregar que, en esta materia los proyectos de Código Civil chilenos se mantuvieron fieles al criterio del encabezamiento del artículo 1108 del Code francés, en donde la causa lícita, se estructura como elemento, presupuesto o parte de la "convención" (convention) $)^{7}$. Además, agrega el Code, como cuarto requisito de la convención (artículo 1108): una causa lícita de la obligación ("une cause licite dans l'obligation") ${ }^{8}$. En este sentido, Guzmán Brito señala las siguientes interpretaciones respecto de la norma precedente: "(i) que la causa de la obligación se identifique con la causa del contrato. Si fuese así, entonces, la agregación de la frase "une cause illicite dans l'obligation", seria redundante" 9 . Agrega Guzmán Brito que: "Tal superfluidad debió resolverse a favor de la causa como condición de la convención, pues es de las condiciones de esta de que precisamente trata el artículo 1108"10,11. (ii) La segunda posibilidad es que existe un vicio en esta

\footnotetext{
$7 \quad$ El artículo 1108 del Code dispone: "Quatre conditions sont essentielles pour la validité d'une convention".

8 Esta norma es extremadamente interesante, toda vez que el encabezado se refiere a las cuatro condiciones esenciales para la validez de la "convención", mientras que el número $4^{\circ}$ de esa misma norma, se refiere a la causa de la "obligación". De aquí entonces, se produjo una dicotomía la "causa de la convención (contrato)" y "causa de la obligación". Dicotomía que el modelo chileno no pudo superar. Como se verá más adelante, existe en el Código Civil chileno una disposición que al definir a la causa dispone que: "Se entiende por causa el motivo que induce al acto o contrato" (artículo 1467 inciso $2^{\circ}$ primera parte); y dos normas que se refieren a la causa como elemento de la obligación (artículos 1467 inciso primero primera parte: "No puede haber obligación sin una causa real y lícita [...]") y artículo 1445: "Para que una persona se obligue a otra por un acto o declaración de voluntad es necesario: [...] $4^{\circ}$ Que tenga una causa lícita”. Surge la pregunta: ¿qué es lo que requiere causa, la obligación o el contrato? En las páginas siguientes se intentará responder a esta interrogante.

GuZMÁN (2005) 216.

GuZMán (2005) 216.

El subrayado es nuestro.
} 
norma, ya que el encabezado de la misma dispone que se requieren cuatro elementos para la validez de la convención, el numero $4^{\circ}$ se refiere a la causa de la obligación. Se ha dicho que el artículo 1108 está viciado por defecto y por exceso: por defecto, ya que una de las cuatro condiciones enunciadas como necesarias para la convención (y se supone que una de ellas es la causa), no fue tratada en él, puesto que de lo que efectivamente trató fue de la causa de la obligación; y por exceso, desde que al tratar de la causa de la obligación lo hizo en sede impropia, pues debió desarrollarla en materia de obligaciones y no de convenciones"12. Esta dicotomía (causa del contrato/causa de la obligación), no aparece en los sucesivos proyectos de código civil, en lo que atinge al artículo que establece las condiciones de validez de un contrato (convención), ya que siempre se referían a "una causa lícita", sin el agregado del Code francés ("dans l'obligation"). Además el verbo "tener" ("que tenga una [...]"), se refiere a que -como se dijo- la causa es un elemento del consentimiento, de tal manera que la norma del artículo 1445 del "Proyecto de 1855", debería leerse de la siguiente forma: "Para que una persona se obligue a otra por un acto o declaración de voluntad, es necesario: [...] $4^{\circ}$ Que el consentimiento tenga una causa lícita ${ }^{13}$. En conclusión, de los proyectos de código civil chileno no se acogió la idea de que la causa era un elemento de la obligación, estableciéndose que dentro de los requisitos de validez del contrato se exige que el contrato tenga una causa lícita. El problema se presentó en el articulado que regula precisamente la causa, de esta forma, con la modificación que hizo el Proyecto de 1855, en que el artículo 1467 inciso $1^{\circ}$ primera parte se expresó: "No puede haber obligación sin una causa real y lícita [...]". Es decir, lo que exige causa es la obligación y no el contrato. En este caso, la regulación criolla no respondió sino a lo establecido en el artículo 1131 del Code francés, el que se refiere a la causa de la obligación, expresando: "L'obligation sans cause ou sur une fausse cause, ou sur une cause illicite, ne peut avoir aucune effet". El Code asimismo, se refiere a la causa de la convención en su artículo 1132 expresando que: "La convention n'est pas moins valable, quoique la cause n'en sois pas exprimée". Esta dicotomía no se refleja en los proyectos de código civil chilenos: en el "Primer Proyecto", la segunda parte del artículo 11 expresa: "La pura liberalidad o beneficencia es causa suficiente en los contratos [...]"; es decir, la causa es un elemento del contrato. Con posterioridad, el artículo 1642 inciso $2^{\circ}$ de "Proyecto de 1853", dice: "Así el contrato dirigido a recompensar un crimen o un acto inmoral, a efectuar un cohecho, a comprar un voto en las elecciones populares o de corporaciones legales, es inválido por el vicio de la causa", en este caso, es también la causa un elemento del contrato. Por su parte el artículo 1647 inciso $2^{\circ}$ del "Pro-

GuZMÁn BRito (2005) 216.

El agregado [en subrayado] es nuestro. 
yecto Inédito de 1853" expresa: "Se entiende por causa el motivo que induce al acto o contrato [...]. Asi la promesa de dar algo en pago de una deuda que no existe, carece de causa; y la promesa de dar algo en recompensa de un crimen o de un hecho inmoral, tiene una causa ilícita"; y entonces, a simple vista, quedaría claro, en la definición misma de causa, que esta se refiere al acto o contrato, al que induce como "motivo". Por último, el "Proyecto Inédito de 1853" fue la norma definitiva que se plasmó como ley de la República en 1855, en este existiría una confusión: en su artículo 1445 , en donde se enuncian genéricamente los requisitos de todo acto o declaración de voluntad para obligar a una persona. El problema se presenta al analizar el mismo artículo 1445, que en su encabezado reza: "Para que una persona se obligue a otra [...]", por tanto no es tan claro que la causa se constituya un elemento de la obligación. Además el artículo 1647 inciso $1^{\circ}$ primera parte del "Proyecto Inédito de 1853" señala: "No puede haber obligación sin una causa real y lícita, pero no es necesario expresarla. [...]". Esta norma (que pasó ser el artículo 1467 del "Proyecto de 1855") exige como presupuesto o elemento para que exista una obligación, el requisito de la causa. Por lo tanto, no es tan claro que esta dicotomía creada por el Code francés, haya sido resuelta por el modelo chileno. Por el contrario, pensamos $-y$ como se demostrará más delante- que el Código Civil chileno no hizo sino establecer una sola causa, que juega como elemento del contrato y elemento de la obligación, asumiendo un carácter subjetivo y objetivo a la vez ${ }^{14}$.

En síntesis, desde el punto de vista de la historia fidedigna del establecimiento de las normas del Código Civil que versan sobre la causa, podría existir una dualidad de causa: por una parte, el Código exigiría una "causa" para el contrato o negocio jurídico y, por la otra una "causa" de la obligación. Pareciera ser, según la tesis tradicional que debemos optar por una de ellas, sin embargo, podría ser que Bello -y creo que eso es lo más acertado- exige causa para el contrato y además, causa para la validez de la obligación. Causas que, no tienen por qué ser diferentes, pudiendo identificarse en una sola noción unitaria. De concluirse lo anterior, ello significaría que el Código de Bello en esta materia, se adelantó a su época, anticipándose a la moderna discusión que, sobre la causa, se ha presentado en el último tiempo.

\section{3) RegulaCión de la CAUSA EN El Código CIVIL CHILENO}

Las siguientes normas del Código de Bello, nos advierten acerca de que la causa es necesaria dentro de nuestro ordenamiento jurídico:

$14 \quad$ El subrayado es nuestro. 
(i) El artículo 1445 inciso $1^{\circ}$ del Código Civil establece que: "Para que una persona se obligue a otra, por un acto o declaración de voluntad es necesario: $1^{\circ}$ que sea legalmente capaz; $2^{\circ}$ que consienta en dicho acto $o$ declaración y su consentimiento no adolezca de vicio; $3^{\circ}$ que recaiga sobre un objeto lícito y, $4^{\circ}$ Que tenga una causa lícita". (ii) A su vez, el artículo 1467 dispone: "No puede haber obligación sin una causa real y lícita, pero no es necesario expresarla. La pura liberalidad o beneficencia es causa suficiente. Se entiende por causa el motivo que induce al acto o contrato; y por causa ilicita la prohibida por la ley, o contraria a las buenas costumbres o el orden público. Asi la promesa de dar algo en pago de una deuda que no existe carece de causa y la promesa de dar algo en recompensa de un crimen o de un hecho inmoral, tiene una causa ilícita". Por último, cabe agregar el artículo 1468 del Código de Bello, establece que: "No podrá repetirse lo que se haya dado o pagado por un objeto o causa ilícita a sabiendas" 15 . Quizás, el fundamento de las normas precitadas, es que la relación jurídica, lleva implícita la condición sine qua non del fin perseguido por los autores de la misma; la causa es una noción que se refiere y justifica la voluntad de las partes, de tal forma que -como ya se dijo- el artículo 1445 No 4 debe entender de la siguiente manera: "Para que una persona se obligue a otra por un acto o declaración de voluntad es necesario: [...] $N^{\circ}$ 4. Que el consentimiento tenga una causa lícita". Como se indicó, y tratando de esbozar una adecuada interpretación de la norma contenida en este artículo, se estima que en esta, se produce un quiebre entre el numeral $1^{\circ}$ (que se refiere a la capacidad legal de las personas) y los restantes números $\left(2^{\circ}\right.$ a $\left.4^{\circ}\right)$ los que -en mi opinión- se refieren al consentimiento, de tal forma que la correcta lectura del artículo $1445 \mathrm{~N}^{\circ} 4$ del Código Civil debiera ser la siguiente: "Para que una persona se obligue a otra por un acto o declaración de voluntad, es necesario: [...] $4^{\circ}$ Que el consentimiento tenga una causa lícita ${ }^{16,17}$.

\section{(3.1) UNA PREGUNTA RELEVANTE: ¿QUÉ REQUIERE LA CAUSA?}

Con el fin de introducir el acápite, es conveniente añadir lo que expresa Alessandri Rodríguez: "Causa de la obligación sería la razón inmediata por la cual el contratante se obliga: en los contratos sinalagmáticos,

15 En este sentido, indica Barcia Lemhann que: "De esta forma, si se declara nulo absolutamente el acto por ilicitud del objeto o de la causa, la restitución de las cosas al estado anterior no permite que se recupere lo dado o pagado por el que cumplió la obligación sabiendo del objeto o causa ilícita que afectaba de nulidad al acto o contrato. Esta norma es una aplicación del principio que nadie puede aprovecharse de su propio dolo o torpeza". Vid. BARCIA Lemhann, Rodrigo (2007) Lecciones de Derecho Civil Chileno. Del acto jurídico. Tomo I. Santiago: Editorial Jurídica de Chile, p. 144

16 Vid. supra nota 29.

$17 \quad$ El subrayado es nuestro. 
la causa de la obligación de una de las partes es la obligación de la otra; en los contratos reales, la causa es la entrega de la cosa que anteriormente hizo el acreedor al deudor; en los contratos a titulo gratuito, la causa es la intención liberal o deseo de hacer un servicio gratuito, desligado de los móviles que difieren en cada disponente. De lo anterior se desprende: a) que la causa de la obligación es abstracta, siempre igual para todas las obligaciones que emanan de un mismo tipo de contrato, representando un concepto técnico; y b) que explica la obligación, el porqué de ella. Causa del contrato sería "el móvil individual principal que determina la celebración de un contrato". Como se ve, el motivo en sentido estricto se erige en causa del contrato que presenta caracteres opuestos a la causa de la obligación: es concreta y cambiante porque no es sino un móvil individual, el principal o más intenso que, por lo mismo, determina la celebración del contrato. Constituye un motivo, y solo se diferencia de los demás que pueden concurrir, por su mayor intensidad, que es la que lleva a contratar. No explica pues, la existencia de las obligaciones, sino la celebración del contrato. Trátase de una causa individual y concreta, eminentemente variable de persona a persona; asi, por ejemplo, una persona puede comprar un caballo para hacer equitación, otra para dedicarlo al cultivo de sus campos, una tercera para regalarlo, etc. el móvil concreto y principal las sentencias francesas lo califican de causa impulsiva y determinante, porque, en oposición a los móviles secundarios, es el que impulsa y determina la contratación" 18 .

Para responder a la pregunta de si nuestro Código Civil ¿se refiere a la causa del negocio o a la de la obligación?, la dogmática civil recurre a tres disposiciones del Código de Bello, que son: (i) Artículo 1445: "Para que una persona se obligue a otra por un acto o declaración de voluntad es necesario: [...] $4^{\circ}$ que tenga una causa lícita", (ii) Artículo 1467 inciso $1^{\circ}$ primera parte: "No puede haber obligación sin una causa [...]", y (iii) Artículo 1467 inciso 2०: "Se entiende por causa el motivo que induce al acto contrato $[\ldots]$ "..

De la sola lectura de estas normas, aparece que no existe entre ellas armonía, ya que las dos primeras señalan que la causa es necesaria para la obligación, mientras que la tercera disposición (precisamente al definir a la causa) asevera que esta es un elemento que se requiere para inducir al acto $o$ contrato. Cobra vigencia la pregunta ¿qué es lo que requiere causa, el contrato o la obligación? En doctrina existen tres respuestas: aquellos que preconizan que la causa constituye un presupuesto de la obligación (Jorge Mera Molina); aquellos que postulan que la causa es un elemento del negocio jurídico (Arturo Alessandri Rodríguez) y aquellos que plantean que

18 Alessandri (1991) 287 y 288. En este sentido, vid. Mazeaud, H. (1960) Lecciones de Derecho Civil. Parte Segunda. Volumen III. Buenos Aires: Ediciones Jurídicas Europa-América, p. 213. 
la causa asume un carácter dualista (Víctor Vial del Río). en las líneas que siguen, trataremos de esbozar una cuarta opinión al respecto ${ }^{19}$.

\section{(3.1.1) La causa es un presupuesto de la obligación}

Jorge Mera Molina señala que, la causa es un presupuesto de validez de la obligación, ya que existen dos normas del Código Civil que prueban que Bello refirió la causa a la obligación. En primer lugar, el artículo 1445. Este dispone textualmente: "Para que una persona se obligue a otra por un acto o declaración de voluntad es necesario: $1^{\circ}$ que sea legalmente capaz; $2^{\circ}$ que consienta en dicho acto o declaración y su consentimiento no adolezca de vicio; $3^{\circ}$ que recaiga sobre un objeto lícito; $4^{\circ}$ que tenga una causa lícita". Según Mera, el verbo "obligue" demostraría que la causa debe existir en la obligación. Sin embargo, Alessandri Rodríguez, critica esta posición, señalando lo siguiente: "[P]ero el enlace gramatical, dentro de la redacción del articulo 1445, no puede existir entre la forma verbal "obligue" y "que tenga una causa lícita". Para evitar esta aberración -según AlEssanDRI- el señor MERA altera la letra de la ley; donde ésta dice "que tenga una causa lícita", él pone "que haya una causa lícita". Si analizamos número por número el artículo 1445, veremos que los predicados corresponden a distintos sujetos, y en forma muy armónica. El $N^{\circ} 1$ alude a la capacidad de la persona que se obliga; el $N^{\circ} 2$, al consentimiento de la misma persona en el acto o declaración de voluntad; el $N^{\circ} 3$, al objeto lícito sobre que debe recaer el consentimiento, y el $N^{\circ} 4$ a la causa licita que debe tener el consentimiento. La causa se liga, pues, al consentimiento que la persona debe prestar en el acto o declaración de voluntad. Este acto o declaración es el que tiene causa, como quiera que el consentimiento es el que lo constituye sustancialmente" 20 . En segundo lugar, MERA sostiene que, la interpretación del artículo 1445 está corroborada por el inciso $1^{\circ}$ del artículo 1467 del Código Civil, conforme al cual "no puede haber obligación sin una causa real y lícita [...]". Esto significaría que la obligación es la que debe tener causa ${ }^{21}$.

19 Claro Solar, Luis (1937) Explicaciones de Derecho Civil chileno y comparado. Tomo VI. Santiago: Imprenta Nascimento; Pescio Vargas, Victorio (1978) Manual de Derecho Civil. Volumen 2. Segunda Edición. Santiago: Editorial Jurídica de Chile; Mera Molina, Jorge (1940) Exposición de la doctrina de la causa. Memoria de Prueba. Escuela de Derecho. Santiago: Universidad de Chile; Vodanovic (1945); León (1961); Hevia Calderón, Ricardo (1981) Concepto y función de la causa en el Código Civil chileno. Santiago: Editorial Jurídica de Chile; Alessandri (1991); Vial del Río, Víctor (2003) Teoría general del acto jurídico. Quinta Edición actualizada y aumentada. Santiago: Editorial Jurídica de Chile.

20 Alessandri (1991) 290.

21 Mera (1940) 124 y ss. 


\section{(3.1.2) La causa es presupuesto del negocio jurídico}

Arturo Alessandri Rodríguez, principal exponente de esta opinión, señala que la causa constituye un presupuesto del acto o contrato. En efecto, dice Alessandri que: "En todos los Proyectos del Código Civil la causa aparece referida al consentimiento o al acto, y jamás a la obligación. La disposición correspondiente al artículo 1445 decía en el Proyecto de 1842: "Todo contrato supone el consentimiento de las partes; y para que este consentimiento sea válido, es necesario: $1^{\circ}$ que los contratantes sean legalmente capaces; $2^{\circ}$ que su consentimiento no adolezca de vicio; $3^{\circ}$ que recaiga sobre un objeto; $4^{\circ}$ que tenga una causa lícita" (Titulo II, art. 1). El mismo texto se reproduce en el Proyecto de 1847 (art. 11) y en el Proyecto de 1853 (art. 1626). En el llamado Proyecto Inédito la causa se enlaza directamente con el acto. En efecto, el inc. $1^{\circ}$ del artículo 1626 de ese Proyecto dispone: "Para que los actos voluntarios produzcan civiles, es necesario: $1^{\circ}$ que la persona que los ejecuta sea legalmente capaz; $2^{\circ}$ que consienta en ellos y su consentimiento no adolezca de vicio; $3^{\circ}$ que recaigan sobre un objeto licito; $4^{\circ}$ que tengan una causa lícita"22. Agrega Alessandri, que: "La redacción del articulo 1445 del Código no es sino, como se ve, trasunto sustancial de la que se empleaba en los correspondientes articulos de los diversos Proyectos. Por la forma en que se encadenan las frases en la disposición vigente llegamos a la conclusión de que la causa se atribuye al consentimiento, y esto es lo mismo que atribuirlo al acto o declaración de voluntad, pues aquel es la esencia de este. En todo caso, un análisis distinto de la redacción solo podría llevar al resultado de que la causa se refiere directamente al acto o declaración de voluntad, pero jamás a la obligación. Por último, cabe agregarse un argumento más a favor de la opinión que sostenemos. Si la legislación da margen para dos o más interpretaciones, parece natural preferir aquella que se conforme a la definición del mismo legislador, pues éste en ella expresa, al menos, la idea básica de la respectiva institución. Y la definición de causa dice que es el motivo que induce al acto o contrato" 23,24 .

Asimismo, y con el fin de apoyar la posición de Alessandri, se puede señalar que en artículo 1445 del Código Civil se produce un "quiebre" entre el número $1^{\circ} \mathrm{y}$ los restantes numerales, ya que el primer número se referiría "exclusivamente" a la capacidad legal de los contratantes; mientas que los restantes números de esta norma se referirían al "consentimiento", de tal manera que la lectura correcta de este artículo debiese ser: "Artículo 1445: Para que una persona se obligue a otra por un acto o declaración de

\footnotetext{
Alessandri (1991) 291.

Alessandri (1991) 291

Vodanovic también sostiene que: "La causa es un presupuesto del negocio, extrañamente, en esta obra se sostiene el concepto clásico de la causa, que aparece incompatible con la atribución de la causa al acto". VODANOVIC (1945) 425 y ss.
} 
voluntad es necesario: $1^{\circ}$ que sea legalmente capaz; $2^{\circ}$ que consienta en dicho acto o declaración y su consentimiento no adolezca de vicio; $3^{\circ}$ que la voluntad recaiga sobre un objeto lícito; $4^{\circ}$ que la voluntad tenga una causa lícita" 25 . La voluntad (en los actos jurídicos unilaterales) y el consentimiento (en los actos jurídicos bilaterales) equivalen al elemento de la esencia general del negocio. Para el Código Civil "causa" y "voluntad" son, en lo sustantivo, una misma cosa, por tanto, si falta la causa es como que faltara la voluntad o el consentimiento, en su caso, y en esta hipótesis el negocio jurídico no nace a la vida jurídica ${ }^{26}$.

Encontramos apoyo a la idea anterior, en la obra Luigi Ferri, que señala: "Podemos tomar como punto de partida el principio establecido por Ihering, segun el cual no hay voluntad sin una finalidad. La concepción normativa del negocio que defendemos implica la existencia, dentro del negocio, de una voluntad, la llamada voluntad negocial, que no es querer subjetivo o querer en acto, sino voluntad normativa, voluntad que se ha objetivado en mandatos juridicos, en normas. La voluntad del sujeto, si ha existido, se ha separado de él, se ha precipitado en el negocio, se ha convertido en algo inherente al negocio, propio de él" $27,28$.

Por último, hay que agregar que, el artículo 1467 del Código Civil, dispone en su inciso $1^{\circ}$ : "No puede haber obligación sin una causa [...]". Con respecto a esta norma, se piensa que si el negocio jurídico no tiene "causa" es "ineficaz"; en doctrina es inexistente, en el Derecho chileno se discute entre la inexistencia o nulidad absoluta, pero, en definitiva, cualquiera que sea la sanción aplicable a ese negocio, este no podrá producir o generar obligación alguna: si no hay causa, entonces no hay acto jurídico y consecuencialmente no hay obligación (por falta de causa eficiente).

25 El agregado (en subrayado) es nuestro.

26 Esta tesis fue acogida por la Corte de Apelaciones de Concepción, la que en fallo de 26 de diciembre de 1910, expresa: "¿Que cuál fue la causa real porque sus mandantes se constituyeron deudores de don Francisco Aldunate, subinspector de alcoholes de este departamento, de la suma de seis mil quinientos pesos, por la escritura de quince de julio último? Que ninguna suma de dinero o cosa fungible, pero absolutamente nada se expresa que hubiera entregado el señor Aldunate a sus mandantes para que éstos se constituyeran sus deudores. Habiendo faltado la causa fundamental para que sus mandantes se constituyeran deudores no hay contrato. Que sabido es que todo contrato que no llega a tener existencia por falta de algunos de sus requisitos esenciales es nulo, artículo 1681 del Código Civil; contrato que no llega a tener existencia, es lo mismo que contrato que no existe o que no ha existido jamás; y por lo mismo que no tiene existencia, no produce ni puede producir efecto alguno". TABOLARI (2010) 937.

27 Ferri, Luigi (2001) La autonomía privada. Traducción y notas de Derecho Español por Sancho Mendizábal, Luis. Granada: Editorial Comares, p. 357.

28 Esta finalidad habrá que buscarla -como dice Redenti-, no en el pensamiento recóndito de las partes, con un sondeo de carácter psicológico, sino en el dictum de la misma ley contractual tal como ha sido establecida. 


\section{(3.1.3) Opinión moderna: la causa es un requisito del contrato y de la obligación (Teoría unitaria de la causa) ${ }^{29}$}

En Francia, como señala Morales, la "[c]ausa, gracias a la evolución jurisprudencial descrita, abandona la necesidad de su dualidad teórica y retoma su esencia subjetiva. Más acorde con una visión del contrato entendido como operación económica y global, la causa deviene unitaria y dinámica"30.

Durante largo tiempo se ha planteado la existencia de una dualidad de causa: la causa de la obligación se refiere al "interés económico" que tuvieron las partes al celebrar el contrato, esta asume así, un carácter " $o b$ jetivo", ya que en los contratos onerosos siempre equivaldría al interés o utilidad que persiguen los contratantes, es decir, la causa sería el interés económico que razonablemente buscan las partes al celebrar un contrato, ello supondría dejar fuera en esta materia a los contratos lucrativos ${ }^{31}$. La jurisprudencia francesa, a partir de la década de los noventa, refiriéndose precisamente a esta dualidad, le ha brindado nuevos aires a este elemento. "Asi-señala Morales-, en lo atañe a la causa de la obligación, la Corte de Casación francesa ha procedido a hacer un análisis subjetivo del concepto de causa para constituirla en instrumento de protección del interés o de la utilidad perseguidas por las partes en la conclusión del contrato, más precisamente, de la economía de este (I) y, en lo que toca a la causa del contrato, refuerza la protección del interés general y evidencia, por otra parte, la liberalización del concepto de buenas costumbres (II)"32.

Para ejemplificar este cambio, Morales cita algunos fallos de la Corte de Casación francesa, de los que se destaca la sentencia de 3 de septiembre de 1993, obra de la tercera sala, en este fallo el tribunal de casación "[...] rechazó la demanda interpuesta por un vendedor de un inmueble que pretendia la nulidad de la venta porque el precio era irrisorio. Para la Corte, el juez de segunda instancia acertó en decir que "en el marco de la economía general del contrato, la venta tenía causa, y por lo mismo, contraprestación real. La venta en cuestión tenía como objeto un predio rural cuyo precio habia sido estipulado por las partes a un franco de la época. Sin embargo, y es en este punto donde existe la particularidad, dicha venta estaba acompañada de una cesión de empresa con todos sus activos y pasivos propiedad del vendedor, que le permitiría a este responder a sus acreedores personales. Teniendo en cuenta este aspecto, la Corte de Casación francesa consideró que no era posible reducir a una simple venta la operación global deseada por las partes

\footnotetext{
29 Por razones de extensión, omitimos la Teoría dualista de la causa, toda vez que ella se encuentra superada en Francia. Sin embargo, ella será analizada brevemente a propósito del tipo de causa que recepciona el Código Civil.

Morales (2009) 185 .

Morales (2009) 174

Morales (2009) 173-174.
} 
y se sirvió de la noción de economía del contrato como medio para tomar en cuenta la realidad de la operación y declarar en consecuencia, su validez"33. Asimismo, conviene citar un fallo del mismo tribunal, en que se deja sin efecto un contrato de arrendamiento de un video club, los hechos de la causa son los siguientes: "En este caso, unos esposos, con la finalidad de crear un establecimiento de este género, arriendan a una sociedad 200 videocasetes, durante el término de ocho meses, pagando por ello un valor de 40.000 francos. Un litigio relativo al pago de dicha suma nace entre arrendador $y$ arrendatarios. En primera instancia, el juez decide anular el contrato por error, mientras que el juez de segunda instancia prefiere fundar la nulidad en la ausencia de causa de la obligación de los arrendatarios de pagar el precio establecido en el contrato. En efecto, en su sentencia, el jude d'appel establece que "la causa, móvil determinante que llevó a la señora [...] a contratar, era la difusión cierta de su clientela de sus videocasetes arrendados a la sociedad [...]. Sin embargo, continúa "ese objetivo no podia ser alcanzado en la comuna de [...], ya que esta no cuenta sino con 1315 habitantes". Ya en casación, la sociedad ataca la sentencia referida apoyándose en la presentación doctrinal clásica de la causa (en los contratos sinalagmáticos la causa de la obligación de una de las partes se encuentra en la obligación de la otra) y revela el hecho que el pago efectuado por los esposos Pillier encuentra su causa en la entrega de los videocasetes objeto del contrato. Sin embargo, y es alli donde reside la novedad, la Corte de Casación decide cambiar la posición clásica que habia sostenido hasta entonces y en un fallo confirmatorio de su primera sala civil, fechada el 3 de julio de 1996, establece lo siguiente: Habiendo revelado que, tratándose del arrendamiento de videocasetes para la explotación de un comercio, la ejecución del contrato según la economía querida por las partes era imposible, la Corte de Apelación con exactitud ha deducido que el contrato se encontraba privado de causa, ya que se probó que la obligación de pagar el precio del arrendamiento de los videocasetes suscrito por el Sr. y la Sra. [...], estaba desprovista de toda contraprestación real"34.

\section{(3.2) REQUISITOS DE LA CAUSA}

Para establecer los requisitos de la causa, se debe distinguir entre la causa de la obligación y la causa del contrato. Sin embargo, nuestro Código los trata conjuntamente en el artículo 1467 inciso $1^{\circ}$, asumiendo que ambos son requisitos de la obligación, en efecto, esta norma dispone que: "No puede haber obligación sin una causa real y lícita [...]"35.

Morales (2009) 175.

Morales (2009) 175-176.

En este sentido, indica Morales lo siguiente: "Este dualismo entre la causa de la obligación y la causa del contrato, latente en la construcción jurisprudencial contemporánea francesa de la causa, se ha mantenido como el mejor medio para garantizar, en cuanto a la primera, un equilibrio 


\section{(3.2.1) La causa de la obligación debe ser real}

Siguiendo la doctrina francesa moderna sobre esta materia, podemos indicar que asumiendo la existencia de una dualidad de causa (causa del contrato y causa de la obligación), la causa de la obligación tendría como requisito su existencia, es decir debe ser real; en cambio, la causa del contrato debe ser lícita. La causa de la obligación debe ser real, y lo es cuando ella efectivamente existe. En este sentido, Alessandri Rodríguez, expresa: "A contrario, no es verdadera la causa si no existe o es falsa. Cuando la causa no existe en ninguna forma, ni en el mundo objetivo ni en el subjetivo, se dice que hay ausencia o falta de causa. Ejemplos: compraventa en que no se pacta precio alguno, donación sin ánimo de liberalidad o de beneficencia, contrato de mutuo sin que se haya entregado al deudor cosa alguna. Cuando la causa solo existe en la mente de los sujetos y no corresponde a la verdad objetiva, se dice que es falsa o errónea. Ejemplo clásico: el heredero que paga un legado sin saber que éste fue revocado en un testamento posterior al que se atiene" 36 . El Code francés nombra separadamente la ausencia de causa y la causa falsa, en su artículo 1131; pero como no existe diferencia alguna entre los dos casos, Bello no siguió al modelo francés en este punto, optando por exigir solamente causa real, expresión que contiene las dos hipótesis precedentes ${ }^{37}$.

minimo y objetivo en las convenciones que permiten a los contratantes protegerse contra la ausencia o apariencia de contraprestación, y en cuanto a la segunda, una protección del interés social que no afecta a la estabilidad contractual". Morales (2009) 173-174.

36 Alessandri Rodríguez, Arturo y otros (1991) Derecho Civil: Parte Preliminar y Parte General, actualizado por Antonio Vodanovic H. Santiago: Ediar, pp. 294 y 295.

37 La jurisprudencia de la Corte de Apelaciones de Puerto Montt, en un fallo reciente (20 de diciembre de 2010), dice en su Considerando Cuarto: "Que en cuanto, a la excepción de nulidad de la obligación contenida en el artículo $464 \mathrm{~N}^{\circ} 14$ del Código de Procedimiento Civil, se funda en la falta de causa, cabe señalar en primer término que como lo ha sostenido la jurisprudencia, de una interpretación armónica de los articulos 12, 28 y 79 de la Ley 18.092, cabe concluir que el carácter abstracto del pagaré, a fin de desatender la causa que le da origen, lo es con el solo efecto de permitir su circulación sin prevenciones de parte de quien lo recibe, esto es, tiene por objeto favorecer a los terceros, quienes no forman parte del negocio juridico que lo motiva, consagrando la inoponibilidad de excepciones personales del obligado respecto de anteriores portadores del documento, imponiendo su satisfacción solidaria a quienes lo suscriben, sin que por ello quede liberado de cualquier otro compromiso. Consecuencialmente dicha abstracción no llega a importar que entre las partes del acto de comercio se desatiendan todos sus antecedentes y pueden por tanto deducirse tanto excepciones reales, que afectan al documento mismo, como las personales que se puedan tener respecto del acreedor". En: www.vlex.com. Asimismo, vid. (respecto de la falta de causa): Dictamen No 27.851 de la Contraloría General de la República, dictado con fecha 18 de noviembre de 1986; Sentencia de la Corte de Apelaciones de Santiago, dictada con fecha 17 de agosto de 2000; Sentencia de la Corte Suprema, dictada con fecha 25 de noviembre de 2001; Sentencia de la Corte de Apelaciones de Santiago, dictada con fecha 24 de diciembre de 2002; Sentencia de la Corte de Apelaciones de Santiago, dictada con fecha 14 de julio de 2003; Sentencia de la Corte de Apelaciones de Santiago, dictada con fecha 18 de mayo de 2004; Sentencia de la Corte de Apelaciones de Santiago, dictada con fecha 24 de diciembre de 2004; Sentencia de la Corte de Apelaciones de Valdivia, dictada con 
En definitiva, las dos expresiones legales "ausencia de causa" y "causa falsa", designan la misma situación, pero considerada desde dos puntos de vista diferentes: si se parte de la comprobación objetiva de que no existe la contraprestación, se concluye que la voluntad no ha tenido una razón válida para comprometerse (ausencia de causa); si se analiza la voluntad misma, se percibe que ha creído falsamente en la existencia de una contraprestación (falsa causa).

Ahora bien, Vial del Río, al respecto, señala que: "Cuando el único motivo del negocio es la creencia errada de que existe obligación que sirve de causa falsa, estamos frente a un error sobre los "motivos", ya que se ha representado erradamente como motivo determinante de la declaración una obligación que no existe" 38 . En el mismo sentido, agrega Melich Orsini, que: "[A] la ausencia o inexistencia de causa hay que homologar la falsedad de la causa, entendida como errónea creencia en la existencia de una causa que luego se comprueba que no existe" 39 . Por su parte, Marty y Raynaud señalan que: "La falsa causa y error sobre la causa tienen el rasgo común de consistir ambos en un vicio del consentimiento: una de las partes ha creido erróneamente en la existencia de la causa. Pero se puede hablar más precisamente de falsa causa cuando el error recae sobre los elementos subjetivos. Asi, el comprador ha creido falsamente en la existencia de la cosa que él creía adquirir, hay falsa causa y la nulidad de su compromiso no es dudosa [...]. Al contrario, una parte ha creido erróneamente poder satisfacer los móviles que le han determinado a contratar: hay error sobre la causa" 40 .

Por otra parte, tampoco existe causa, cuando ella es "simulada". Como indica Alessandri Rodríguez: "Causa simulada es la que se hace aparecer públicamente en un acto juridico, y que no es la verdaderamente querida por los autores del acto jurídico, la cual permanece disimulada o secreta. De aqui que, técnicamente, la causa simulada no es una falsa causa; esta supone un error y aquella es obra intencional. Por si misma, la causa simulada no produce la nulidad del acto o contrato de que forma parte.

fecha 28 de marzo de 2006; Sentencia de la Corte Suprema, dictada con fecha 6 de julio de 2006; Sentencia de la Corte Suprema, dictada con fecha 20 de julio de 2006; Sentencia de la Corte de Apelaciones de Santiago, dictada con fecha 29 de diciembre de 2006; Sentencia de la Corte de Apelaciones de Santiago, dictada con fecha 7 de agosto de 2007; Sentencia de la Corte de Apelaciones de Temuco, dictada con fecha 3 de julio de 2008; Sentencia de la Corte de Apelaciones de San Miguel, dictada con fecha 28 de julio de 2010; Sentencia de la Corte de Apelaciones de San Miguel, dictada con fecha 13 de agosto de 2010; Sentencia de la Corte de Apelaciones de Puerto Montt, dictada con fecha 10 de diciembre de 2010; Sentencia de la Corte de Apelaciones de Iquique, dictada con fecha 22 de marzo de 2011; Sentencia de la Corte de Apelaciones de Valdivia, dictada con fecha 27 de abril de 2011. Vid. www.vlex.com

38 VIAL (2003) 203

39 Melich Orsini, José (1984) La causa en la teoría del contrato y sus diversas funciones. En Anuario de Derecho Civil. Tomo XXXVII. Fascículo I. Madrid: p. 45.

40 MeLICH (1984) 25. 
En efecto, si la simulación es absoluta, es decir, si se finge celebrar un acto jurídico y en realidad no se quiere celebrar ninguno, propiamente no hay ninguna causa; si la simulación es relativa, o sea, si las partes fingen celebrar un acto jurídico y en realidad celebran en secreto otro, que es el que verdaderamente quieren, el acto disimulado o secreto es el que vale entre las partes, y si su causa existe y es lícita, el acto es plenamente válido. En caso de que la causa del acto oculto no existiera o fuera ilícita, la nulidad de este se debería a la falta de causa o a la ilicitud de ella, pero no a la simulación. En resumen, por si sola la simulación de la causa no determina la nulidad del acto" 41,42 .

Ahora bien, conviene esbozar algunas notas en torno a la simulación: en general, se habla de "simulación" toda vez que las partes de un contrato, manifiestan una voluntad diversa de su intención o voluntad real, esta voluntad "aparente" puede no encubrir ningún acto jurídico, en ese caso estamos frente a una simulación "absoluta", o bien puede encubrir un acto jurídico disimulado, en cuyo caso estamos frente a una "simulación relati$v a^{\prime \prime} 3$.

Como indica Emilio Betti: "Existe simulación cuando las partes de un negocio bilateral, de acuerdo entre ellas -o el autor de una declaración con destinatario determinado en inteligencia con este- dictan una regulación de interés distinta de la que piensan observar en sus relaciones, persiguiendo a través del negocio un fin (disimulado) divergente de su causa típica. Fin divergente que a) puede ser también de autonomía privada, caracterizando un tipo de negocio diferente al simulado, o b) puede ser de naturaleza contraria, extraño al cometido de la autonomía privada. En la hipótesis (a), la simulación se acostumbra a denominar relativa (por ejemplo, se celebra una venta para un fin de donación, o una venta con facultad de retracto para un fin de mutuo con garantía real). En la segunda hipótesis (b), en la que la intención práctica de las partes no se dirige a ningún negocio, la simulación se suele llamar absoluta (por ejemplo, se realiza una enajenación sin ninguna causa que pueda justificarla; solo para sustraer a los acreedores la garantía constituida

41 Alessandri (1991) 295.

42 En este sentido, la Corte de Apelaciones de Santiago, declaró que: "No obsta a la validez de la obligación la simulación de la causa, si la causa verdadera y oculta es perfectamente lícita [...]". Gaceta de los Tribunales, Tomo II, n 3.966, p. 887.

43 En este sentido, vid. Ferrara, Francesco (2002) Simulación de los negocios jurídicos. Volumen 4. Colección Grandes Maestros del Derecho Civil. Serie obligaciones, contratos, garantías y pruebas, y negocios jurídicos. México: Editorial Jurídica Universitaria. Respecto de la simulación, vid. también: Cano Martínez de Velasco, José Ignacio (1990) La exteriorización de los actos jurídicos: su forma y la protección de su apariencia, Barcelona: Bosch, Casa Editorial S. A., Capítulo IV, pp. 93 y ss.; Alonso Pérez, Mariano (1969) El error sobre la causa. En Estudios CASTÁN. Tomo III, Pamplona: pp. 7 y ss.; Kohler, Studien ubre mentalr. und Simulation, Jhering's Jarhrb, p. 130; FitTing, Die Grundlanger der Beweislast, resumido por Polacco, en el Archivio giuridico, Volumen 42, p. 344. 
por los bienes del deudor)" ${ }^{44}$. Ahora, frente a una simulación absoluta, lo único que hay es un acto jurídico aparente, por lo tanto aquí no habrá causa. Se dice que en este caso, la nulidad se produce por falta de causa. En el caso de la simulación relativa debemos averiguar lo que ocurre en el acto jurídico oculto o disimulado, ya que este responde al verdadero querer o intención de sus autores, si no tiene causa es ineficaz porque le falta este elemento. Si tiene causa será eficaz porque reúne este antecedente necesario de los actos jurídicos ${ }^{45}$.

\section{(3.2.2) La causa del contrato debe ser lícita}

La causa del contrato debe ser "lícita". El Código establece que se entiende por causa ilícita "[...] la prohibida por la ley, o contraria a las buenas costumbres o al orden público", artículo 1467 inciso 20 segunda parte. Por ejemplo, "[...] la promesa de dar algo en recompensa de un crimen o de un hecho inmoral, tiene una causa ilícita". Como indica Alessandri Rodríguez: "Aqui se plantea un problema. Si [...] el Código Civil entiende por causa la que la doctrina llama causa final, que es constante, abstracta e igual para cada tipo de acto o contrato, tendremos que concluir que los móviles individuales y concretos no deben ser considerados aunque sean contrarios al orden público, la ley o las buenas costumbres; y si la causa final no presenta estos caracteres, el acto será válido. $Y$ los actos o contratos que por causa (final) ilicita podrán ser anulados en el hecho casi no existirán; se limitarán a los actos innominados, como los que pone por ejemplo el Código, pues los nominados están estructurados por el legislador y es inconcebible que este pueda moldear actos con causa ilícita. De este modo el control de la moralidad de los actos jurídicos queda prácticamente reducido a la nada. Solo en los actos innominados, que las partes mismas (y no el legislador) estructuran en sus elementos básicos, es posible la existencia de la causa (final) ilicita"46, 47.

44 Betti, Emilio (2000) Teoría General del negocio jurídico. Traducción y concordancias por Martín Pérez, A. Granada: Editorial Comares, pp. 344 y 345.

45 Se ha fallado que: "No obsta a la validez de la obligación la simulación de la causa verdadera u oculta es perfectamente lícita”. Gaceta de los Tribunales. Tomo II. Sent. 3.966, p. 887.

46 Alessandri (1991) 295. Una opinión que no compartimos, tienen algunos autores nacionales: Así, Alessandri Besa señala que: "Esta reducción del control ético sobre los actos jurídicos ha aparecido como un grave problema en doctrina. Los autores postulan una tesis absurda con el fin de atenuarlo: se sostiene que para determinar la existencia de la causa hay que considerar la causa final; pero para fijar la ilicitud es preciso atender a los móviles individuales y concretos". Alessandri Besa, Arturo (1949) La nulidad y la rescisión en el Derecho Civil chileno. Santiago: Imprenta Universitaria, p. 195. En este mismo sentido, León (1961) 30.

47 En lo que atinge a los conceptos de "moral" y "buenas costumbres", conviene puntualizar qué es lo que entiende por ellas. Para Ferri, "[...] la moral ha de entenderse en sentido subjetivo, como voluntad buena, intención dirigida a lo bueno y justo, mientras que las buenas costumbres tienen un carácter objetivo y externo. "Quien ve la moral en las buenas costum- 
Como señala Melich: "La noción de causa ilícita permite sancionar aquellos contratos en que, no obstante ser lícitos en si y aisladamente considerados los objetos de las obligaciones que se crean por su intermedio, son utilizados por las partes para obtener fines ilícitos o inmorales. A través de esta noción se logra, en efecto, un control extrinseco de la conformidad del contrato con los fines generales del ordenamiento jurídico" 48 . Por su parte, Ripert y Boulanger señalan que: "Un convenio es ilícito generalmente por su objeto. Para que haya causa ilícita, es necesario que las partes se hayan propuesto infringir una regla legal en la organización de sus relaciones. Asi ha sucedido con ciertos convenios que han sido concertados en previsión de una depreciación monetaria: se habia estipulado, por ejemplo, que el monto de la deuda sería calculado en francos de acuerdo al tipo de cambio de una moneda extranjera (libra o dólar). El objeto de la obligación era lícito, puesto que el pago debía realizarse en billetes de Banco de Francia, pero la causa no lo era, ya que los contratantes habian querido vulnerar el valor legal del franco" ${ }^{49}$. Por otra parte, es conveniente agregar la opinión de Lacruz, quien estima que: "Un contrato puede ser meramente ilegal cuando infringe la carga general que recae sobre los contratantes de adoptar los medios adecuados a los fines que persiguen. Por ejemplo, las partes no pueden, mediante contrato, volver objetivamente inalienable una cosa, aumentar el numero de derechos reales, o declarar inscribible el mero hecho de poseer. Un contrato con este contenido es un contrato inutil: una tentativa fracasada. Pero no es un contrato ilícito ni, en sentido estricto, ilegal. Para que un contrato sea ilegal es preciso que incumba, no una carga, sino un deber impuesto por el ordenamiento. La doctrina suele distinguir entre ilegalidad en sentido estricto y la ilicitud del contrato: la primera, infracción por los contratantes, de una concreta ley prohibitiva o imperativa; la segunda implica la disconformidad del contenido del contrato con la moral social. La reprobación genérica del contrato ilegal o ilícito llega al Cc. a través de las leyes de Partidas, una de las cuales, siguiendo al Derecho romano y la tradición canonista, establece que "todo pleyto que es fecho contra nuestra ley, o contra buenas costumbres, que no debe ser guardado; Maguer pena o juramente fresse puesto en el" $(5,11,28)$. En el Cc. esa ley vierte su contenido en tres lugares distintos: En el art. 1225, que

bres adopta una concepción exterior o farisaica de aquella”. Pero en nuestro Derecho, no se encuentran razones para sostener esa opinión que parece confundir la moral con la buena fe. Más probablemente, esas expresiones serían sinónimas. Como indica De Castro: decir que la causa no sea contraria a la moral significa que la conducta impuesta en aquellos no se oponga a la exigible "en la moral convivencia de las personas estimadas honestas". A su vez Marty y Raynaud hablan de las "exigencias de moralidad de una civilización". Estas opiniones podrían perfectamente ser aplicadas en nuestro Derecho. Lacruz (2000) 452. Sobre la "causa ilícita", vid.: Sentencia de la Corte de Apelaciones de Santiago, dictada con fecha 18 de julio de 2003.

$48 \quad$ Melich (1984) 47.

49 Ripert-Boulanger (1963) 206. 
autoriza a los contratantes a establecer los pactos, cláusulas y condiciones que tengan por conveniente, siempre que no sean contrarios a las leyes a las moral, ni al orden público. En el art. 1.271 que después de autorizar la contratación sobre las cosas que están en el comercio de los hombres, y prohibirla sobre la herencia futura, establece que pueden ser igualmente objeto de contrato todos los servicios que no sean contrarios a las leyes o a las buenas costumbres. $Y$ en el Art. 1275, según el cual los contratos [...] con causa ilícita, no producen efecto alguno. Es ilícita la causa cuando se opone a las leyes o a la moral (véanse, además, arts. 1.116, 1.304 y 1.305, 1.316, etc.). La figura que contempla el art. 1.275 al referirse a la causa ilícita, poco tiene que ver con las tres clases de causa descritas en el 1.274, las cuales, en si mismas, no pueden ser inmorales. No lo es nunca el sentimiento de generosidad, el ánimo liberal, pero aun en los supuestos de contrato oneroso la prestación o retribución solo puede ser inmoral por su consistencia (ilicitud del objeto), o por la finalidad de la parte que presta, y entonces fuera del concepto objetivo de causa" 50 .

En nuestro Derecho, dijimos, que constituye causa ilícita "[...] la prohibida por la ley, o contraria a las buenas costumbres o al orden público [...]" (Art. 1467 inciso $2^{\circ}$ segunda parte del Código Civil). Ahora bien, el carácter ilícito o inmoral de los fines del negocio no es algo que pueda presumirse, ya que no corresponde a una situación normal u ordinaria, y es por ello que deberá ser comprobado por aquel que lo alegue en el caso concreto. En este sentido, señala Melich que: "Se ha señalado que las hipótesis, en que para impugnar un contrato ilícito o inmoral se requiere acudir a la idea de la ilicitud o inmoralidad de la causa, son relativamente raras. Cuando de modo manifiesto el contrato no satisface todos los elementos necesarios para su perfeccionamiento y validez o cuando su objeto es ilícito, no se presenta la necesidad de tener que comprobar que, con la celebración del mismo, las partes han buscado eludir o rebajar la observancia de una norma o de un principio básico del ordenamiento en la organización convencional de sus relaciones" 51 . Por último, como indica el italiano Betti: "La ilicitud moral de la causa no ha de apreciarse según los principios teóricos de una ética particular, religiosa o filosófica, sino conforme a las exigencias éticas de la que al tiempo del negocio es la conciencia social colectiva, la opinión pública de la sociedad. Tales exigencias constituyen propiamente el "ethos" o las "buenas costumbres" (boni mores), son decisivas para determinar el valor social de los intereses que a través del acto buscan satisfacción" 52 .

En síntesis, se estima que la "causa" aparece como aquella institución -dentro de muchas otras-, tales como la doctrina de la imprevisión, las obligaciones naturales, el principio de la buena fe, la teoría del ejercicio

LACRUZ (2000) 448 y 449.

Melich (1984) 300 y 301.

BetTi (2000) 323. 
abusivo de los derechos, el vicio de la lesión enorme, la doctrina del error común, la teoría de las apariencias, etc., cuya principal finalidad es velar porque los negocios jurídicos respeten principios fundamentales del Derecho Civil (por ejemplo la buena fe, el enriquecimiento sin causa), denotando con ello, un substrato moral que no solo los justifique, sino que precisamente, constituya la razón o fundamento de la atribución patrimonial que de ese negocio se origine.

\section{(3.3) TIPO DE CAUSA QUE CONSAGRa El CÓdigo DE BELlo}

El problema se ha presentado, tradicionalmente, de la siguiente manera: ¿el Código Civil chileno se refiere a la causa final de que habla la teoría clásica, a la causa ocasional o a ambos tipos de causa? Esta cuestión ha sido debatida y la mayoría de la doctrina nacional se pronuncia por la causa final, que es constante, uniforme y abstracta para todos los actos o contrato $^{53}$. Sin embargo, en el último tiempo, la doctrina francesa agrega una nueva tendencia: la causa constituye a la vez un requisito de la obligación y del contrato, asumiendo un carácter unitario y dinámico.

Analicemos pues, estas cuatro posibilidades:

\section{(3.3.1) El Código Civil acoge la doctrina de la causa final}

Podrían invocarse los siguientes fundamentos, a favor de esta conclusión: En primer lugar, habría una razón histórica. Como indica Hevia: "La tesis tradicional (a la que suele llamarse teoría de la causa final) era universalmente aceptada al momento de la dictación del Código, y, por tanto, este estaría imbuido de ella, sin haberse apartado en este punto de la doctrina instaurada por Domat y Pothier, seguida por el Código de Napoleón y por sus comentaristas; y no podría ser de otro modo, salvo que se pensara en una genialidad de Bello, merced a la cual el Código chileno se hubiera anticipado a los tribunales franceses en la idea de concebir la causa como motivo determinante ( $y$ no ya como un fin abstracto, juridico), lo cual aconteció varias décadas después" 54 . Agrega Hevia, que: "Por otra parte, al exigir nuestra ley una causa real, lo que hace, en verdad, es exigir la causa como tal: que la causa sea real, se dice, significa simplemente que la causa debe existir. La ley exige que la obligación tenga una causa, y esto confirmaria la tesis tradicional, pues si se exige causa es porque ella puede faltar (sería absurdo exigir lo que necesariamente no puede faltar), y el motivo

\footnotetext{
53 Alessandri (1991) 292 y ss.; Alessandri (1991) 187; Claro (1937) 309 y ss.; León (1961) 28 y ss.; Mera (1940) 32. En doctrina comparada, vid. también: Giorgi (1930) Teoría de las obligaciones. Tomo III. Segunda edición revisada. Madrid: Editorial Reus, $\mathrm{n}^{\circ}$ 437, p. 460.

$54 \quad$ HeVia (1981) 79.
} 
concreto necesariamente existe, siempre, por caprichoso o excéntrico que sea; si el Código razona sobre la base de ausencia de causa es porque no la concibe como motivo (es decir como fin concreto y contingente), sino como fin abstracto y jurídicamente considerado" 55 . Por ello dice Avelino León, que el ejemplo del Código: "[L]a promesa de dar algo en pago de una deuda que no existe, carece de causa" (artículo 1467 inciso 20 segunda parte), confirma lo dicho; en efecto, escribe este autor: "No hay causa porque no hay obligación anterior y, normalmente habrá falsa causa porque el que hace la promesa solo se obligará por su creencia de que existe esa obligación, o sea, porque para él hay una causa falsa, lo que equivale a decir que no hay causa" 56, 57. En segundo lugar, el Código Civil expresa que: "[...] la mera liberalidad es causa suficiente" (artículo 1467 inciso $1^{\circ}$ parte final), pues bien, la mera liberalidad es, precisamente, la causa típica que la doctrina de la causa final asigna a los contratos lucrativos. Se trata de una causa abstracta y constante, correspondiente a esa categoría de negocios. Por último, cabe preguntarse lo siguiente: ¿Por qué Bello definió a la causa como el "motivo"? Se dice que fue por un error de lenguaje: el legislador simplemente "olvidó" agregar el vocablo "jurídico", de tal forma que la definición correcta de causa, debería haber sido la siguiente: "Se entiende por causa el motivo juridico que induce al acto o contrato" 58 .

\section{(3.3.2) El Código Civil chileno acoge la doctrina de la causa ocasio- nal o impulsiva}

Los fundamentos en que se basa esta posición son los que siguen: En primer lugar, como indica León: "Respecto del "argumento histórico", se puede responder lo siguiente: los propios creadores de la teoría de la causa, los canonistas, "establecieron, olvidando la estabilidad del contrato, que el juez debia juzgar también la moralidad de la relación jurídica, es decir, la

\footnotetext{
Hevia (1981) 79. Sin embargo, confiamos en la genialidad del maestro Bello. LEÓN (1961) 51.

En este sentido, Jean Domat y Roberto José Pothier. Vid. León (1961) 24 y ss.

Nuestra jurisprudencia así lo ha confirmado; en efecto, la Corte de Apelaciones de Valparaíso, en sentencia de fecha 11 de enero de 1923, estableció que: "[...] la causa de un contrato es el interés jurídico, que induce a las partes a contratar, interés que es distinto e independiente del móvil utilitario o subjetivo que hayan podido tener en cuanta al momento de celebrar el contrato. Así, en los contratos bilaterales la causa para que una de las parte la constituye la obligación contraida por la otra, la prestación que ésta debe satisfacer. Son ajenas a la determinación de la causa las modalidades de la obligación contraida [...]". Vid. Corte de Apelaciones de Valparaíso, 11 de enero de 1923, Gaceta 1924, 20 sem., No 57, p. 314, secc. 1ª, p. 669; Corte Suprema, 10 de septiembre de 1924. G., 1924, $2^{\circ}$ sem., No 25, p. 133, t. 24, secc. $1^{\text {a }}$, p. 678. Vid. también R. D. y J., Tomo XXIII, secc. $1^{\circ}$, p. 669; Tomo XXIV, secc. $1^{\circ}$, p. 678. En este sentido, vid. también Alessandri (1991); Claro (1937); Ducci Claro, Carlos (2007) Derecho Civil. Parte General. 4a Edición. Santiago: Editorial Jurídica de Chile.
} 
causa del contrato, los móviles que determinaron a contratar"' 59,60 . Incluso, como indica Domat: "El móvil o motivo concreto ocupa el lugar de causa con respecto a las liberalidades: la mera liberalidad es, para él, un motivo"61. Por ello, el argumento no es definitivo, la cuestión no puede plantearse en términos de una imposible anticipación genial de BeLLo con respecto a la orientación ulterior de los tribunales franceses, pues estos no crearon una nueva concepción de la causa, sino que revalidaron una existente.

Ahora bien, cuando el Código Civil define a la causa señala que se entiende por tal "el motivo que induce al acto o contrato" (artículo 1467 inciso $2^{\circ}$ primera parte). La palabra "motivo" tiene una clara connotación subjetiva o psicológica que, en el texto de la norma, no aparece con ningún adjetivo (no se indica, por ejemplo: "motivo jurídico", "motivo jurídico-económico", "motivo inmediato", etc. En otras palabras, no existe duda alguna de que el legislador acepta la doctrina de la causa ocasional, pues Bello empleó el vocablo "motivo" como sinónimo de la voz "causa". Por otra parte, en ese contexto, el vocablo aparece utilizado con su precisa significación, en forma reiterada y consciente ${ }^{62}$. Por otra parte, es posible rebatir el argumento de los partidarios de la doctrina de la causa final, conforme al cual el Código Civil acogería la causa final al decir que: " $\mathrm{La}$ pura liberalidad o beneficencia es causa suficiente" (artículo 1467 inciso $1^{\circ}$ parte final), ya que, ante todo, debe dilucidarse el concepto de "mera liberalidad".

Respecto de la idea conforme a la cual el Código Civil chileno exigiría la existencia de una causa, es decir, que esta esté presente como tal, con lo cual desplazaría a la noción de causa como motivo concreto y determinante (este siempre existe, no es necesaria su exigencia), indica Hevia, lo siguiente: "(a) El artículo 1445 del Código Civil dispone: "Para que una persona se obligue a otra por un acto o declaración de voluntad es necesario: [...] $4^{o}$ que tenga una causa lícita". Esta norma exige no la causa

59 En este sentido, señalan Ourliac y De Malafosse: "Más aún, si los romanos no hicieron de la causa una condición general de validez de los contratos, no dudaron, sin embargo, en emprender el análisis psicológico necesario para determina los motivos individuales y concretos [...]". Ourliac y De Malafosse (1960) Derecho romano y francés histórico. Barcelona: Casa Editorial Bosch, p. 289.

60 León (1961) 21

61 Domat, Jean (1977) Les loix civiles dans leer ordere natural; le droit public et legumdelectus. París: Chez Cellot, Libraire-imprimeur, p. 20.

62 Así solo algunos preceptos antes de aquel en que se define la causa como motivo, al referirse al error como vicio de la voluntad, la ley habla de "motivo principal" (artículo 1454 del Código Civil) y de "causa principal" (artículo 1455 del Código Civil), haciendo sinónimos los términos "motivo" y "causa"; y ello sin que se pueda estimar que los vocablos carecen, en estos preceptos, de su contenido psicológico: lo que sucede es que mientras los artículos 1454 y 1455 disciplinan el efecto del error en el motivo principal, el artículo 1567 disciplina el efecto de la ilicitud del motivo principal. Con esta interpretación se resguarda la debida correspondencia y armonía que, debe existir, entre las diversas partes de la ley. (Artículo 22 del Código Civil). 
como tal, sino un atributo o cualidad de ella: su licitud, es decir, que no sea prohibida por la ley o contraria a las buenas costumbres o al orden público. (Articulo 1467 inciso $2^{\circ}$ segunda parte). Por su parte, el inciso $1^{\circ}$ de esta norma establece: "No puede haber obligación sin una causa real y licita [...]", nuevamente, lo que se exige son dos atributos o cualidades de la causa, y no de la causa como tal: en efecto, se exigen la realidad y licitud de la causa. El artículo 1468 se refiere también a la causa ilícita, poniendo de relieve el adjetivo, el atributo: esto es lo que cuenta. Por último, el artículo 1682, al determinar las causales de nulidad absoluta, se refiere expresamente solo a la causa ilícita. b) ¿Qué significa que la causa sea real? Se ha pensado que exigir causa real es lo mismo que exigir causa, y que inexistencia de causa real es lo mismo que inexistencia de la causa. Estimamos que, por el contrario, al exigir causa real y lícita se están exigiendo dos atributos de la causa, pero no la causa misma. Debe tenerse en cuenta, en este punto, la sugestiva modificación del texto de nuestra ley con relación a su modelo francés: en tanto que el artículo 1131 del Código de Napoleón dice "la obligación sin causa, o fundada sobre una causa falsa o sobre una causa ilícita, no puede tener ningún efecto", el artículo equivalente de nuestro Código no se refiere a la obligación sin causa; solo expresa que la causa debe ser real y lícita"63, 64. Ahora bien, esta distinta redacción que da la ley chilena, explica la distinta concepción de causa que él tiene: siendo la causa un móvil o motivo determinante y concreto, no cabe seńalar que "la obligación sin causa, o fundada sobre una causa falsa [...] no puede tener ningún efecto"; de ahí entonces, que nuestro Código Civil diga, simplemente, que: "No puede haber obligación sin una causa real y lícita [...]". La exigencia de causa aparece, pues, ligada al concepto de causa como motivo. En efecto, si concurren varios motivos, pero solo uno de ellos es determinante, entonces, este es la causa real. Se agrega que el juez debe discriminar entre los diversos motivos, hasta identificar aquel que determinó la voluntad del sujeto. Por último, en lo que atinge al ejemplo que el Código Civil da en cuanto a que: "[...] la promesa de dar algo en pago de una deuda que no existe, carece de causa", se cree que, pese a su tenor literal, no se refiere a la causa en el sentido de la definición legal. La norma se refiere expresamente a la "causa ilícita", mas no a la "ausencia de causa". Sin embargo, se dice que la ausencia de causa (a la cual se asimila el error en la causa) queda incluida en el artículo 1682, cuando dispone: "[...] la omisión de algún requisito o formalidad que las leyes prescriben para el valor de ciertos actos o contratos en consideración a la naturaleza de ellos [...]", produce nulidad absoluta. Sin embargo, en ninguna disposición del Código se exige a la causa como un requisito

\footnotetext{
$63 \quad$ Hevia (1981) 83 y 84.

64 En este sentido, el Código Civil italiano de 1865 señalaba, igualmente, que "[l] a obligación sin causa, o fundada sobre una causa falsa o ilícita, no puede tener ningún efecto" (artículo 1.119), expresando también la hipótesis de inexistencia de causa.
} 
de validez del negocio, pues los artículos 1445 y 1467 del Código Civil se refieren a la "causa lícita". Además, el artículo 1682, en la parte recién citada, habla de ciertos actos o contratos, y, en todo caso, la presencia de la causa no es una exigencia de ciertos contratos solamente, sino de todos, pues se postula como un requisito general de validez. Se desprende de lo dicho, que el Código Civil, al expresar que la promesa de dar algo en pago de una deuda que no existe, carece de causa, no está afirmando que esta causa (o fundamento, como indica el Código en el artículo 2297) sea necesaria para la validez del acto: solamente es necesaria para que lo pagado no quede sujeto a repetición. El pago de lo no debido es un remedio independiente de la nulidad. La causa, en cambio, está profundamente ligada a la nulidad ${ }^{65}$.

\section{(3.3.3) El Código contiene dos especies de causa (Doctrina ecléctica)}

Conforme a esta doctrina, se acepta la causa, entendida como el fin abstracto y típico respecto de la causa lícita (causa final); pero respecto de la causa ilícita se acoge la noción de causa ocasional. Es decir, existirían dos especies de causa ${ }^{66}$.

\section{(3.3.4) El Código Civil acoge la doctrina unitaria de la causa final}

Creemos que, al instituto de la causa se le debe otorgar un tratamiento unitario: la causa sirve para justificar a la obligación (entendida como el "interés económico" que persiguen las partes al contratar), lo que supone darle vida al requisito de la realidad de la causa y, al mismo tiempo, utilizarla como sinónimo de "motivo", lo que permitiría analizar el tema de la licitud de la misma (causa del contrato). En efecto, nuestro Código, al igual que el francés ${ }^{67}$, define a la causa ilícita como "la prohibida por la ley, o contraria a las buenas costumbres o al orden público", por ello, es a través de la revisión de la licitud de la causa, el momento propicio para que, el tribunal analice los motivos que tuvieron las partes para contratar, a la luz de conceptos como el orden público o las buenas costumbres. Lo anterior, significaría un notable avance en nuestro Derecho,

65 A nivel de Derecho comparado, encontramos el artículo 1831 del Código Civil Federal mexicano, el cual expresa: "El fin o motivo determinante de la voluntad de los que contratan, tampoco debe ser contrario a las leyes de orden público ni a las buenas costumbres". Vid. Código Civil Federal y Código Federal de Procedimientos Civiles Mexicano (2006) Ciudad de México: Berbera Editores S. A., p. 221.

$66 \quad \mathrm{Al}$ respecto, expresa Hevia, que: "Esta posición es el resultado de la constatación de la esterilidad de la tesis tradicional frente al problema de la ilicitud de la causa, y supone un reconocimiento parcial de la tesis del motivo determinante". Hevia (1981) 92. VIAL (2003) 204-205.

67 El artículo 1132 del Code, dispone que: "La causa es ilícita, cuando es prohibida por la ley, cuando es contraria al orden público o las buenas costumbres". 
ya que la causa, ahora entendida como noción unitaria, estaría presente durante toda la vida del contrato y, no se agotaría a la fase de las tratativas preliminares y a la fase de la celebración del acto jurídico.

En Francia, siguiendo a Morales, la "[c]ausa, gracias a la evolución jurisprudencial descrita, abandona la necesidad de su dualidad teórica y retoma su esencia subjetiva. Más acorde con una visión del contrato entendido como operación económica y global, la causa deviene unitaria y dinámica. En este sentido, un primer anteproyecto de reforma al libro III, titulos III y IX del código civil francés, realizado bajo la dirección de Pierre Catala, recogía estos avances, precisando y unificando el concepto. Bajo el titulo de "Cause de l'engagement", traducible al español como "Causa del compromiso". La causa se define en el artículo 1124 como la justificación del mismo, "la razón por la cual el derecho positivo le reconoce efectos juridicos. Su existencia y su licitud continuan siendo requisitos. En cuanto a la primera, este proyecto restringía su apreciación a la etapa de formación del contrato, para evitar desequilibrios entre los postulados de justicia contractual y seguridad jurídica, la causa en los contratos onerosos, incluso para aquellos celebrados a favor de un tercero, sería el provecho esperado de la celebración del contrato, el interés o causa final, análisis que permite tener en cuenta los motivos que fueron previamente integrados al campo contractual y la apreciación del conjunto del objeto contractual"68.

\section{(3.4) SANCión A LA FALTA DE CAUSA Y A LA CAUSA ILÍCITA}

En la doctrina nacional, no ha sido pacífica la opinión en torno a si don Andrés Bello contempló o no la doctrina de la inexistencia en el Código Civil chileno. En este sentido, los autores nacionales se han alineado en dos posturas irreconciliables: (i) aquellos que postulan que el Código Civil chileno si contempló la sanción de la inexistencia; y (ii) aquellos autores que seńalan que el Código Civil no acogió la teoría de la inexistencia. La vieja controversia iniciada entre José Clemente Fabres y Antonio Varas, se ha mantenido con Arturo Alessandri Rodríguez y Luis Claro Solar y posteriores autores ${ }^{69}$. Aquellos que señalan que la teoría de la inexistencia

\footnotetext{
68 Morales (2009) 185.

69 La disputa entre la inexistencia y la nulidad absoluta comenzó en el siglo XIX entre José Clemente Fabres y Antonio Varas (el primero a favor de la nulidad absoluta como máxima sanción en nuestro Derecho y el segundo como defensor de la teoría de la inexistencia); y, se ha mantenido inexorablemente en el tiempo. No es del caso analizar detalladamente los argumentos por los cuales cabría acoger una u otra tesis; pero, en todo caso, es posible consultar: Barros Errázuriz, Alfredo (1932) Curso de Derecho Civil. Volumen III Santiago: Editorial Nascimento; Claro (1937); Vodanovic (1945); Alessandri Besa (1949); Alessandri Rodríguez (1991); Figueroa Yáñez, Gonzalo (1995) Curso de Derecho Civil. Tomo II. Teoría de los actos jurídicos. 3a Edición. Santiago: Editorial Jurídica de Chile; Pescio (1978); Vial (2003); Ducci (2007); Barcia (2007).
} 
no se contempla en nuestro Código Civil (principalmente Arturo Alessandri Rodríguez), postulan que la máxima sanción que establece el Código Civil es la nulidad absoluta. Los argumentos que se esgrimen para defender esta opinión, son los siguientes:

En primer lugar, el Código Civil no regula de forma orgánica la doctrina de la inexistencia, todavía más, no la contempla como sanción ni tampoco regula sus consecuencias; en cambio en el Libro IV, Título XX titulado "De la nulidad y rescisión", establece los efectos que produce la omisión de un requisito que la ley exige, para que un acto jurídico exista, y tenga validez. Por otra parte, como señala Alessandri: "[...] nuestro Código Civil solo reconoce la nulidad absoluta y la relativa, comprendiendo los actos inexistentes entre los actos nulos de nulidad absoluta. Razones para pensar de este modo son las que siguen. $1^{\circ}$ Así lo da entender el artículo 1682 cuando dice que es nulidad absoluta "la producida por la omisión de algún requisito o formalidad que las leyes prescriben para el valor de ciertos actos o contratos en consideración a la naturaleza de ellos, y no a la calidad o estado de las personas que los ejecutan o acuerdan", con lo cual quedan englobados todos los requisitos que se exigen, tanto para la validez como para la existencia de los actos jurídicos. $2^{\circ}$ El Código Civil no se ha ocupado siquiera de reglamentar los efectos que produce la inexistencia del acto, de manera que los actos en doctrina son inexistentes, entre nosotros son nulos de nulidad absoluta. Es cierto que hay algunas disposiciones del Código Civil que permiten dar margen a la creencia de que en Chile también tiene cabida la teoría de la inexistencia jurídica. Así el artículo 1460 dispone que toda declaración de voluntad debe tener por objeto una o más cosas que se trata de dar, hacer o no hacer; pues bien, este precepto ha hecho pensar algunos que significa que no puede haber declaración de voluntad sin objeto, y que una declaración sin objeto sería inexistente. Análogo argumento se hace en presencia del artículo 1467, que expresa que "no puede haber obligación sin una causa real y licita"; del artículo 1701, según el cual "la falta de instrumento público no puede suplirse por otra prueba en los actos o contratos en que la ley requiere esa solemnidad, y se mirarán como no ejecutados o celebrados aun cuando en ellos se prometa reducirla a instrumento público dentro de cierto plazo, bajo una cláusula penal: esta cláusula no tendrá efecto alguno". Los que sostienen la teoría de la inexistencia dentro de nuestro Código, estiman que los citados artículos consideran los actos a que se refiere, como si nunca hubieren existido. Lo cierto es que todas estas disposiciones, traducción fiel de las pertinentes del Código francés, pueden dar margen para sustentar la teoría de la inexistencia jurídica. Pero llegando al título de la nulidad y la rescisión (nulidad relativa), que es el título en que la ley se encarga de reglamentar los efectos que produce la omisión de los requisitos exigidos para las declaraciones de voluntad, la doctrina de la inexistencia no halla asidero alguno, porque únicamente distingue y reglamenta la nulidad ab- 
soluta y la nulidad relativa, como desde el comienzo lo deja en claro el artículo 1681. Este precepto, concluye el señor Alessandri, es, entonces, el desmentido más convincente a los que sostiene la teoría de la inexistencia. $3^{\circ}$ El legislador declara absolutamente incapaces a los dementes [...]. Con esto se manifiesta que, en su concepto, dichas personas están totalmente privadas de razón, y que por consiguiente, el requisito de la voluntad no existe en los actos que ellos ejecutan; dichos actos son inexistentes por falta de voluntad. Ahora bien, el artículo 1682 dice que hay nulidad absoluta en los actos y contratos de los absolutamente incapaces. ¿No está demostrando esto que dentro de la nulidad absoluta engloba el legislador también los actos inexistentes?"70,71.

En segundo lugar, Claro Solar sostiene que el Código Civil acoge la teoría de la inexistencia y sustenta su tesis en los siguientes argumentos:

De los artículos 1444 y 1681 se desprende claramente que Bello distinguió la inexistencia de la nulidad. La primera norma indica "[...] si falta una de las cosas esenciales al perfeccionamiento de un contrato como tal, no produce efecto alguno, o degenera en otro diferente: no dice que el contrato a que falte ese requisito esencial, sea nulo". El artículo 1681 expresa que "Es nulo todo acto o contrato a que falta alguno de los requisitos que la ley prescribe para el valor mismo del acto o contrato según su especie y la calidad o estado de las partes: no expresa que el acto o contrato sea nulo si falta alguno de los requisitos exigidos para su existencia, sino que se refiere a requisitos prescritos para el valor, para la validez, del acto o contrato". La distinción entre la inexistencia y la invalidez o nulidad, continúa Claro Solar, aparece de manifiesto en muchos artículos del Código: 1701, 1801, 1802, $1809,1814,2027,2055,2057$, etc. $^{72}$.

70 Alessandri (1991) 325 y 326.

71 En este sentido, vid.: Alessandri (1991) 325 y 326; Claro Solar (1979), XII, vol. III, pp. 580 y ss.; Barros (1930) 140 y ss. La jurisprudencia de la Corte Suprema ha acogido este criterio. Así en el fallo de casación, de fecha 9 de septiembre de 2010 ha dicho lo siguiente: " 4 ". - Que en el recurso de casación en el fondo, fundamentando su solicitud, el recurrente expresa que en el fallo cuestionado se infringen los artículos 19, 20, 22, 23, 24, 1443, 1444, 1445, 1467, 1681, 1682 y 1683 del Código Civil; $57 N^{o} 4$ y 6 y 67 Nos 9 y 13 de la Ley 18.046; y 27 y 28 de los Estatutos Sociales de la sociedad demandante, reiterando sus argumentos en orden a que la omisión de las formalidades requeridas para la enajenación de los activos de la sociedad y la falta de causa real y lícita que la justificara, debió llevar a los sentenciadores del mérito a concluir la nulidad absoluta de los contratos de compraventa sub lite e, incluso, a declararla de oficio, por aparecer de manifiesto en los actos jurídicos impugnados [...]". Sin embargo, respecto de este mismo punto ("falta de causa"), Vid. también: Sentencia de la Corte Suprema de 7 de abril de 2010; Sentencia de la Corte de Apelaciones de Santiago, dictada con fecha 2 de mayo de 2005; Sentencia de la Corte de Apelaciones de La Serena, dictada con fecha 29 de diciembre de 2006; Sentencia de la Corte de Apelaciones de Chillán, dictada con fecha 23 de marzo de 2009. En www.vlex.com

72 Claro Solar (1937) 582 y ss. El artículo 1701 dice que "la falta de instrumento público, no puede suplirse por otra prueba en los actos o contratos en que la ley requiere esa solemnidad, y se mirarán como no ejecutados o celebrados aun cuando ellos se prometa reducirlos a instrumento público dentro de cierto plazo, bajo una cláusula penal: esta cláusula no tendrá efecto alguno". 
Respecto de la consideración relativa a que el Código Civil sanciona con la nulidad absoluta los actos y contratos ejecutados o celebrados por personas absolutamente incapaces, debiendo sancionarlos con la inexistencia, si distinguiera esta de la nulidad, Claro Solar justifica su teoría en los siguientes términos: "La incapacidad absoluta o natural de los dementes [...], proviene de su falta de discernimiento e imposibilidad de tener y manifestar una voluntad consciente. En el hecho, estas clases de personas no consienten en el acto o contrato que ejecutan, no pueden dar a conocer su verdadera voluntad y podría decirse que falta en el acto o contrato el consentimiento y no puede perfeccionarse; pero como pueden aparentemente consentir, la ley expresamente declara que adolece de nulidad absoluta el acto o contrato de las personas absolutamente incapaces, y habia dicho ya que sus actos no producen ni aun obligaciones naturales o no admiten caución (artículo 1447)"73.

Otro sostenedor de la doctrina de la inexistencia justifica de manera diferente la sanción impuesta el legislador a los actos de los absolutamente incapaces: "Por lo demás, dice, si el legislador bien pudo privar de todo valor la declaración de voluntad de estos incapaces, no pudo desconocer que la hacen y en alguno casos con discernimiento y voluntad. De aqui que haya preferido no establecer la inexistencia directa del acto o contrato que celebra"74, 75 .

Exigido como solemnidad para el perfeccionamiento del acto o contrato el instrumento público, si falta este, no existe el acto ante la ley y debe mirarse, no como nulo, como defectuoso, sino como no ejecutado el acto o no celebrado el contrato; los interesados nada han hecho, aunque se comprometan a reducirlo a escritura pública dentro de determinado plazo, bajo cláusula penal, esta cláusula no tendrá efecto alguno porque no puede garantizar un acto o contrato que no tiene existencia, que no puede producir efecto civil alguno. Del mismo modo, el artículo 1801, después de establecen que la venta se reputa perfecta desde que las partes han convenido en la cosa y en el precio, dice que "la venta de los bienes raíces, servidumbres y censos y la de una sucesión hereditaria, no se reputan perfectas ante la ley, mientras no se ha otorgado escritura pública": la solemnidad de la escritura pública es requerida para el perfeccionamiento del contrato, para su existencia ante la ley. En el contrato de sociedad expresa igualmente el artículo 2055, que "no hay sociedad, si cada uno de los socios no pone alguna cosa en común, ya consista en dinero o efectos, ya de una industria, servicio o trabajo apreciable en dinero". Este requisito es esencial a la existencia de la sociedad, como también lo es la participación de beneficios: no se trata de una sociedad nula, cuya nulidad absoluta sea necesario declarar para que cesen los efectos del contrato, sino de una sociedad que carece de existencia jurídica. Claro Solar (1979) 588 y 589.

73 Claro Solar (1979) 600 y 601.

74 Ortúzar Escobar, Enrique (1938) De la inobservancia de la ley en relación con los actos jurídicos. Memoria de Prueba, Santiago: Escuela de Derecho de la Universidad de Chile, p. 111.

75 En este sentido, vid. también (por orden cronológico): Labandera y Blanco, V. (19131914) Nulidad, anulabilidad y rescindibilidad en el Cc. En Revista de Derecho Privado, Madrid, pp. 171 y ss.; Moreno Mocholi, M. (1946) Las irregularidades en el negocio juridico. En Revista de Derecho Privado, Madrid, pp. 21 y ss.; Borrel y Soler, Antonio María (1947) Nulidad de los actos jurídicos según el Código Civil español. Barcelona: Bosch); Albaladejo, Manuel (1958): Ineficacia e invalidez del negocio jurídico. En Revista de Derecho Privado, Madrid, pp. 603 y ss.; De los Mozos, José Luis (1960) La inexistencia del 
En Francia, frente a la "ausencia de causa" se dice que la sanción es la nulidad, ya que "[e]l contrato que no se ajusta a las condiciones de validez establecidas por la ley es nulo. De hecho, la revocación retroactiva elimina el contrato, el que se considera que nunca se celebró. Las partes deben volver al estado anterior a la celebración del mismo [...]"76. Establecido lo anterior, surge la pregunta ¿la sanción a la falta de causa es la nulidad absoluta o la relativa? A este respecto, agregan estos autores: "Por último, la ausencia de causa [...] se castiga de forma diferente dependiendo de si se acepta la teoría clásica o la moderna de la nulidad. En vista a la teoría clásica, la sanción es la nulidad absoluta, porque se omite un requisito esencial del acto. A la luz de la teoría moderna, es la nulidad relativa, ya que esta tiene la función de castigar la transgresión de una norma que se propone proteger los intereses de la contraparte, que no ha recibido lo que se justifica por el contrato"77. Aun cuando la nulidad relativa parece prevalecer en la opinión de la jurisprudencia, existen algunos fallos que aplican la nulidad absoluta para la falta de causa $(v$. gr. sentencia de la Corte de Casación, de fecha 9 de noviembre de 1999).

Por último, respecto de la sanción aplicable a la existencia de una causa ilícita, según el artículo 1682 inciso $1^{\circ}$ primera parte del Código Civil la sanción es la nulidad absoluta ${ }^{78}$. La sanción es sin discusión la nulidad absoluta, así lo establece el artículo 1682 inciso $1^{\circ}$ primera parte del Código Civil.

negocio jurídico. En Revista General de Legislación y Jurisprudencia, Madrid, p. 486; De Castro (1991) 461 y ss.; Díez-Picazo, Luis (1961) Eficacia y ineficacia del negocio jurídico. En $A D C$, Madrid, pp. 506 y ss.; Delgado Echeverría, Jesús (1976) La anulabilidad. En ADC, Madrid, pp. 1021 y ss.; Bonet Correa, José (1976) Los actos contrarios a las normas y sus sanciones. En ADC, Madrid, p. 309; Espín Cánovas, D. (1977) La nulidad en el Derecho Civil. En "Homenaje a Segismundo Royo-Villanova", Madrid: Moneda y Crédito, p. 233; Clavería GosálBez, Luis Humberto (1977) La confirmación del contrato anulable. Bolonia: Publicaciones del Real Colegio de Espańa; De los Mozos, José Luis (1983) La nulidad de los actos jurídicos. En Libro de Homenaje al Prof. Luis Martin-Ballesteros. Zaragoza: Editorial Tecnos, pp. 481 y ss.; Gordillo Cañas, Antonio (1983) Violencia viciante, violencia absoluta e inexistencia contractual. En Revista de Derecho Privado, Madrid, pp. 214 y ss.; López Beltrán de Heredia, Carmen (1996) La nulidad contractual. Consecuencias. Valencia: Tirant lo Blanch, pp. 1 y ss.; Pasquau Liaño, Miguel (1997) Nulidad y anulabilidad del contrato. Madrid: Civitas S. A., p. 1 y ss.

76 Borisov, Plamen; Gantzer, Nicolas; Hug, Jonathan y Visovan, Cristian (2005) La sanction de l'absence de cause. Seminaire de M. le Profesesseur Simler, Droit des Obligationis et des Bienes, Le 22 mars 2005, p. 9.

77 Borisov-Gantzer-Hug-Visovan (2005) 10

78 Vid. Saborido Sánchez, Paloma (2005) La causa ilícita: Delimitación y efectos. Valencia: Tirant Monografías. 


\section{4) Conclusiones}

Lo que se ha denominado "Teoría de la causa" tiene probablemente dos grandes etapas bien definidas en su evolución en Francia. De las primeras manifestaciones causalistas elaboradas teóricamente a partir de los trabajos de Jean Domat (Lois civiles dans leur ordre naturel, París, 1694), a quien se le debe la existencia de la noción de "causa real", que luego perfeccionaría Robert Joseph Pothier (Traité des obligations, París, 1761) a quien se le debe la introducción de la noción de "causa ilícita", ambos en el siglo XVII, se inicia el "causalismo objetivo". Sus conclusiones y estudios fueron los que recogieron los redactores del Código de Napoleón en las reglas de los artículos 1108 y particularmente en los artículos 1131 a 1133. Esta posición objetiva de la causa, seguida por Charles Demolombe (Cours de Code de Napoléon, París, 1827), Antoine-Marie Demanté (Cours analytique de Code civil, Paris, 1849), Charles Aubry y Charles Rau (Cours de Droit civil francais, París, 1838) o Alexandre Duranton (Cours de droit francais suivant le code civil, París, 1844), por solo mencionar algunos, privilegiaba la razón inmediata que movía a las partes a contratar, la que se presentaba como una razón abstracta, siempre presente en cada tipo de contrato ${ }^{79}$.

La célebre idea hasta hoy reconocida para los contratos sinalagmáticos típicos por cuya virtud la causa de la obligación de una de las partes, es el objeto de la prestación de la otra se impone, así como su corolario que hace concluir que, si una de las partes no cumple su obligación, habría ausencia de causa. La causa así planteada, entonces, no es necesario expresarla pues se presume en cada contrato típico.

Esta posición causal, encuentra la virulenta crítica de Marcel Planiol (Traité élémentaire du droit civil, París, 1928) quien pretende demostrar que ella sería al mismo tiempo falsa, ilógica e inútil, con lo que nace con él, aunque antes ya había sido esbozado por Gabriel Baudry-Lacantinérie (Traité théorique et pratique de droit civil, Paris, 1906) el primer movimiento anticausalista en Francia. La falsedad de la noción la hacen descansar en la inexistencia de la causa en un Derecho romano formalista que no la exigía; la acusación de ilógica en tanto se basaba en que sustentar la existencia de la causa de la obligación de una de las partes en la obligación de la otra haría de la causa un elemento que desaparecería junto al contrato tan pronto las obligaciones se extinguieran. En fin, la inutilidad de la causa, la acusaban en la confusión de esta noción con el objeto.

La teoría clásica de la causa entretanto se perfeccionaba y complementaba por movimientos causalistas subjetivos, principalmente en los

79 Vid. Ruz LÁrtiga, Gonzalo (2011) Explicaciones de Derecho Civil. Parte General y Acto Jurídico. Tomo I. Santiago: Editorial AbeledoPerrot, LegalPublishing Chile, pp. 421 y ss. 
trabajos de Louis Josserand (Les mobiles dans les actes juridiques du droit privé: Essais de téléologie juridique, París, 1928). En efecto, la tesis causalista debe su conformación dualista de la época a la gran contribución de este jurista francés al introducir la noción de "móviles", con lo cual se siembran las bases del subjetivismo causal y el control de la licitud de la causa. Josserand contribuye principalmente al subjetivismo causal al exigir como determinante el móvil impulsivo, concluyendo que si este motivo era inmoral la causa sería ilícita. Con ello el dualismo causal permite delatar al acto jurídico o contrato perfectamente causado para la concepción clásica, pero que pudiera resultar viciado a la luz de la teoría de los móviles. El subjetivismo causal en todo caso ya había sido iniciado brillantemente por Henri Capitant (De la cause des obligations, París, 1927), pero es con Jacques Maury (Essai sur la notion d'équivalence en droit civil francais, Toulousse 1920), a comienzos de los ańos 20, que ya se realizaba una férrea defensa del causalismo, concretando las bases dogmáticas de la teoría subjetiva de la causa que concluye que el fin (but) que mueve a las partes a contratar no es una razón abstracta sino concreta, que variaría -en consecuencia- para cada tipo de contrato.

Conforme a lo anterior, la jurisprudencia comenzó a afirmar esta teoría dualista de la causa que optaba por la coexistencia de una causa objetiva y otra subjetiva. La búsqueda de la causa era diferente según si se analizaba la existencia o la licitud de ella. El juez francés comienza entonces a considerar la existencia de la causa a la luz de la teoría objetiva, permitiendo anular el contrato desde que aparece desprovisto de prestación contraria, por lo que la existencia de la causa juega un rol protector del interés individual, mientras que el control de la licitud de la causa se ampara en la teoría subjetiva, lo que permitirá anular el contrato si ella es contraria a la moral, el orden público o las buenas costumbres, con lo cual esta se erige como protectora del interés colectivo.

La segunda etapa a la que nos referíamos en la evolución de la causa, se origina con una suerte de movimiento "neoanticausalista", que comienza a desarrollarse a partir de los trabajos preparatorios de los distintos esfuerzos doctrinarios privados tendientes a unificar el Derecho de los contratos y de las obligaciones en Europa. Los "Principios Unidroit", los "Principios Europeos del Derecho de los Contratos" y el "Anteproyecto de Código Europeo de los Contratos", son tal vez las manifestaciones más palpables, bajo la influencia del Common Law británico, de este movimiento que acusa como responsable de comprometer la unificación jurídica en Europa a la existencia de conceptos abstractos como el de la causa.

La reacción de la doctrina francesa es probablemente la que asienta la denominada "Teoría unitaria de la causa", que representa el último movimiento neocausalista o de defensa de la noción en el Derecho continental. La noción de causa hasta antes del nacimiento de este movimiento, había pasado por las experiencias renovadoras de la causa en los trabajos doc- 
torales de Judith Rochfeld en París (Cause et type de contrat, Paris, LGDJ, 1999), en l'école de droit d'Aix con Arnaud Cermolacce (Cause et exécution du contrat, PUAM, 2001) y Van Dai Do (Le role de l'intéret privé Dans le contrat en droit francais, PUAM, 2004), estos dos últimos dirigidos por el Decano Jacques Mestre, los que habían renovado la noción de causa acercándola a la noción de interés, con lo cual probablemente se dieron los elementos principales para que el Profesor Jacques Ghestin alzara la voz ( $\mathrm{La}$ cause de l'engagement et la validité du contrat, Paris, LGDJ, 2006). GHestin es uno de los redactores del denominado "Projet Catala", con el que se comienzan a desarrollar una serie de estudios de modernización del Derecho de las obligaciones en Francia.

La teoría unitaria de la causa, concluye que la causa cumpliría un rol tan importante que el debate sobre retener una causa objetiva o subjetiva es estéril, pues ambos estaban presentes y servían de control de los objetivos o intereses de las partes o de la colectividad en el contrato. Así hoy, hay un renovado consenso en Francia, en cuanto a que tanto las nociones de causa objetiva (causa real) como causa subjetiva (causa lícita) son necesarias. La primera, la realidad de la causa o teoría objetiva, principalmente en el campo de la obligación, se erige como el medio más eficaz de dejar sin efecto el contrato al desnudar la ausencia de contraprestación recípro$\mathrm{ca}$, resguardando el interés privado de las partes; $y$, la segunda, en el campo del acto jurídico o contrato y su formación, a través de la licitud de la causa o teoría subjetiva, como medio para proteger el interés general, al controlar los motivos contrarios a la moral, el orden público o las buenas costumbres, que se esconden en la voluntad generadora del acto.

Por ello, el debate actual en nuestro país, en materia de causa, creemos que radica en la "necesidad" de su mantenimiento. Ello, a la luz de la actual discusión suscitada en Europa, en torno a la posibilidad de eliminarla como elemento constitutivo de los actos jurídicos.

Creemos que las viejas discusiones en torno a la causa, que se plantean a modo de pregunta: a) ¿qué es lo que requiere causa? y b) ¿qué tipo de causa consagra el Código Civil chileno?, están superadas por doctrina moderna. Por ello, nuestro norte debe apuntar a las nuevas orientaciones que sobre esta materia nos entregan los autores franceses. En este punto podemos citar a Ghestin, Larroumet, Rieg, entre otros. A partir de la experiencia gala, la jurisprudencia nacional podría vigorizar la noción de causa, otorgándole el verdadero sitial que ella se merece.

Frente al grave atentado en contra de la causa, particularmente asestados por "Los principios de Derecho europeo de los contratos" y por el "Anteproyecto de Código Europeo de Contratos", nos situamos, con más entusiasmo que lucidez, en el bando de los juristas franceses que intentan justificar su existencia.

En conclusión, creemos que la causa constituye un concepto "unitario", el que sirve para justificar a la obligación (causa entendida como el 
interés económico que persiguen los contratantes), y al contrato (la causa entendida como el o los motivos personales que llevaron a las partes a contratar); la primera noción se traduce en la existencia de causa; en cambio, la segunda incide en la licitud de la misma. Lo anterior se satisface con los requisitos que le exige el Código a la causa: ella debe ser "real" y "licita".

Por último, no podemos sino agradecer la genialidad del maestro Andrés Bello, que se adelantó en más de ciento cincuenta años a las modernas discusiones que, sobre la causa, se han planteado en el Derecho comparado moderno, otorgando luminosas notas acerca del instituto de la causa, a diferencia de lo que se ha planteado hasta ahora.

\section{BIBLIOGRAFÍA}

\section{a) Autores extranjeros}

Albadalejo García, Manuel (1993) La causa. Tomo 42. Madrid: Revista de Derecho Privado. Bosch.

(1993) El negocio jurídico. 2a Edición. Madrid: Librería

Alonso Pérez, Mariano (1967) La esencia del contrato bilateral. Salamanca: Ediciones Universidad de Salamanca.

(1969) El error sobre la causa. En Estudios de Derecho Civil en honor al Profesor Castán Tobeñas. Tomo III. Pamplona: Ediciones Universidad de Navarra.

Aristóteles (1937) Metafísica En Obras Completas. Volumen II. Buenos Aires: Bibliográfica Omega.

(1970): Metafísica (Edición Trilingüe por Valentín García Yebra, Madrid, Editorial Gredos).

Atiyah, P. S. (1995) An introduction to the law of contract. Quinta Edición. Oxford: Clarendon Press.

Barassi, Lodovico (1955) Instituciones de Derecho Civil. Volumen I. Traducción Ramón García de Haro. Madrid: Bosch.

Barcia López, Arturo (1966) La causa ilícita en las obligaciones y en los actos jurídicos. Buenos Aires: Editorial Abeledo-Perrot.

Betti, Emilio (2000) Teoría General del negocio jurídico. Traducción y concordancias por A. Martín Pérez. Granada: Editorial Comares.

Bonnecase, Julián (1945) Elementos de Derecho Civil. Tomo II. Derecho de las obligaciones, de los contratos y del crédito. Traducción José M. Cajica Jr., México: Editorial José M. Cajica Jr.

Borisov, Plamen; Gantzer, Nicolas; Hug, Jonathan y Visovan, Cristian (2005) La sanction de l'absence de cause. Seminaire de M. le Profesesseur Simler, Droit des Obligationis et des Bienes, Le 22 mars 2005. 
Cabral De Moncada, Luis (1956) Derecho positivo y ciencia del Derecho. En El hecho del Derecho. Buenos Aires: Editorial Losada.

Capitant, Henri (1927) De la causa de las obligaciones. Traducción de Eugenio Tarragato y Contreras, Madrid: Góngora.

Colin y Capitant (1908) Cours Elementaire de Droit Civil Français. París.

Cossio, Carlos (1969) La causa y la comprensión en el Derecho. 4a Edición. Estudios Egológicos Fundamentales $N^{\circ} 7$. Buenos Aires: Juárez Editor S. A.

Coviello, Nicolás (1938) Doctrina General del Derecho Civil. México: Editorial Hispanoamericana.

Cueva García, Manuel (1939) El problema de la causa en el Derecho Civil $y$ en el Derecho Cambiario. Quito: Imprenta Universidad Central.

Dabin, Jean (1929) La teoría de la causa. Traducción, notas y concordancias con la legislación española y las americanas por Francisco de Pelsmaeker. Madrid: Librería General de Victoriano Suárez.

De Castro y Bravo, Federico (1991) El negocio jurídico. Madrid: Civitas.

De la Cámara Álvarez, Manuel (1978) Meditaciones sobre la causa. En Revista Crítica de Derecho Inmobiliario, n 527. Madrid.

De los Mozos, José Luis (1961) La causa del negocio jurídico. En Revista de Derecho Notarial, $n^{\circ}$ 33-34, julio-diciembre. Madrid.

De Page, Henri (1957) L'obligation abstraite en Droit interne et en Droit comparé. Traducción de Janette Escobar. Bruselas.

Díaz Cruz, Mario (1964) Causa y "consideration" en los contratos. Inútiles ejercicios de dialéctica. En Comparative Judicial Review, Volumen I, Florida, USA.

Díez-Picazo, Luis (1963) El concepto de causa en el negocio jurídico. Madrid: Separata del Anuario de Derecho Civil. (1966) La tradición y los acuerdos traslativos en el Derecho español. En Anuario de Derecho Civil, Tomo XIX, Fascículo Tercero, julio-septiembre de 1966, Madrid.

(1979) Fundamentos del Derecho Civil patrimonial. Volumen I. Quinta Madrid: Edición, Editorial Civitas.

Díez-Picazo, Luis y Gullón, Antonio (1999) Sistema de Derecho Civil. Volumen II. Octava Edición. Madrid: Editorial Tecnos S. A.

Domat, Jean (1977) Les loix civiles dans leer ordere natural; le droit public et legumdelectus. Paris: Chez Cellot, Libraire-imprimeur.

D’ors, Álvaro, Derecho Privado Romano, Ediciones Universidad de Navarra, S. A., Pamplona, 1991.

Dualde, Joaquín (1949) El concepto de causa de los contratos (La causa es la causa). Barcelona: Bosch.

Enneccerus, Ludwig, Kipp, Theodor y Wolff, Martín (1955) Tratado de Derecho Civil. Madrid: Bosch. 
Entenza Escobar, Pedro (1965) Causa y consideration. En Revista de Derecho Puertorriqueño. Año IV. Universidad Católica de Puerto Rico. Puerto Rico.

Espert Sanz, Vicente (1968) La frustración del fin del contrato. Prólogo de Luis Díez-Picazo. Madrid: Editorial Tecnos.

Ferri, Giovanni (1968) Causa e tipo nello teoria del negozio giuridico. Milán: Dottore A. Giuffré Editore.

Ferri, Luigi (2001) La autonomía privada. Traducción y notas de Derecho Español por Luis Sancho Mendizábal. Granada: Editorial Comares.

Flume, Werner (1998) El negocio jurídico. Parte general del Derecho Civil. Traducción de José María Miquel González y Esther Gómez Calle. Madrid: Fundación Cultural del Notariado.

Galgano, Francesco y Monareti. P. G. (2000) Causalidad y abstracción del contrato: la contraposición entre los modelos francés y alemán. En Atlas de Derecho Privado, traducción de Juan Antonio Fernández Campos y Rafael Verdera Server, Madrid: Fundación Cultural del Notariado.

Galindo Garfias, Ignacio (1996) Teoría general de los contratos. México: Editorial Porrúa S. A.

Galli, Enrique (1935) El problema de la causa y el Código Civil argentino. La Plata.

GAMARRA, Jorge (1952) Estudio de las modernas doctrinas sobre la causa con referencia al derecho positivo oriental. En Revista de la Facultad de Derecho y Ciencias Sociales. Tomo 3. $\mathrm{N}^{\circ} 1$. Montevideo.

García Monge y Martín, Jacinto (1964) Contratos con causa ilícita. En Revista de Derecho Privado. Tomo XLVIII. Madrid: Revista de Derecho Privado.

Garribotto, Juan Carlos (1985) La causa final del acto jurídico. Buenos Aires: Abeledo-Perrot.

Giorgi, Jorge (1930) Teoría de las obligaciones en el Derecho Moderno. Segunda Edición Revisada. Madrid: Editorial Reus.

Giorhgianni, Michele (1961) La causa del negocio giuridico. Milán: Dottore A. Giuffré.

González, A. y otros (1944) Derecho Civil. Buenos Aires.

Gore, Francois. (1949) L’Enrichissement Aux Dépens D’Autrui. París: Librairie Dalloz.

Gorla, Gino (1959) El contrato. Tomos I y II. Traducción José Ferrandis. Madrid: Bosch.

Gorostiaga, Norberto (1944) La causa en las obligaciones. Buenos Aires: Ed. Ideas.

Josserand, Luís (1946) Los móviles en los actos jurídicos de Derecho Privado. Traducción de Eligio Sánchez Larios y José María Cajica. Puebla: Editorial Cajica. 
(1950) Derecho Civil. Tomo II. Buenos Aires: Ediciones Jurídica Europa-América, Bosch y Cía.

Justiniano (1889) Cuerpo del Derecho Civil Romano. Institutionum D. Iustiniani. Primera Edición, Traducción y compilación de Ildefonso García del Corral, Barcelona: Jaime Molinas Editor-Consejo de Ciento no 287).

Lacruz Berdejo, José Luis y otros (2000) Elementos de Derecho Civil. II Derecho de Obligaciones. Volumen Primero. Parte General. Teoría General del Contrato. Segunda Edición revisada y puesta al día por Francisco Rivero Hernández. Madrid: Dykinson.

Lafaille, Héctor (1940) La causa de las obligaciones en el Código Civil y en la Reforma. Buenos Aires.

Larenz, Karl (1956) Base del negocio jurídico y cumplimiento de los contratos. Traducción de Carlos Fernández Rodríguez. Madrid: Editorial Revista de Derecho Privado.

Larroumet, Christian (1999) Teoría general del contrato. Volumen I. Traducción de Guerrero R. Bogotá: Editorial Temis S. A.

Ledesma Narváez, Marianella (1997) Ejecutorias supremas civiles, 19931996. Lima: Editorial Legrima S. R. L.

León, Henry y Mazeaud, Jean (1956) Lecons de Droit Civil. Tomo II, París.

López Vilas, Ramón (1965) Los llamados negocios jurídicos abstractos. En Revista de Derecho Privado. Tomo XLIX. Madrid.

Marías, Julián (1986) Historia de la Filosofía. Primera Reedición en Alianza Universidad Textos. Prólogo de Xavier Zubiri. Epílogo de José Ortega y Gasset, Madrid: Alianza Editorial.

Martín-Ballesteros, Luis (1956) De la causa en los negocios jurídicos contractuales. En Revista General de Legislación y Jurisprudencia. Tomo XXXXII (Segunda Época). Madrid.

Martínez Alfaro, Joaquín (1998) Teoría de las obligaciones. Quinta Edición aumentada y actualizada. México: Editorial Porrúa S. A.

Mazeaud H. y L. y Mazeaud, J. (1960) Lecciones de Derecho Civil. Parte Segunda. Volumen III. Buenos Aires: Ediciones Jurídicas Europa-América.

Melich Orsini, José (1997) Doctrina general del contrato. 3a Edición corregida y ampliada. Caracas.

(1984) La causa en la teoría del contrato y sus diversas funciones. En Anuario de Derecho Civil. Tomo XXXVII. Fascículo I. Madrid.

Messineo, Francesco (1954) Derecho Civil y Comercial. Tomo II. Buenos Aires.

(1946) Doctrina general del contrato. Buenos Aires: Editorial Jurídica Europa-América.

Millán, Enrique (1946) De la evolución conceptual de la causa. En Estudios de Derecho, Universidad de Antioquia. Medellín. 
Morales Huertas, Margarita (2009) La renovación del concepto de causa en el Derecho francés. En Revista de Derecho Privado, Madrid.

Oertmann, Paul (1933) Introducción al Derecho Civil. Traducción de la $3^{a}$ edición alemana por Luis Sancho Seral. Barcelona: Editorial Labor S. A.

Ourliac, Paul y De Malafosse, J. (1960) Derecho romano y francés histórico. Barcelona: Casa Editorial Bosch.

Ossorio Morales, Juan (1932) La doctrina de la "consideration" en el Derecho contractual inglés. (Bol. N $\left.{ }^{\circ} 19\right)$. Granada: Ediciones Universidad de Granada.

Petit, Eugene (1978) Tratado elemental de Derecho Romano. Buenos Aires: Editorial Albatros.

Planiol, Marcel y Ripert, Georges (1945-47) Tratado práctico de Derecho Civil francés. Traducción española del Dr. Mario Díaz Cruz. La Habana: Cultural S. A.

Pothier, Roberto José (1961) Tratado de las obligaciones. Buenos Aires: Editorial Bibliográfica Argentina.

Puig Brutau, José (1978) Fundamentos de Derecho Civil. Tomo II. Volumen I. Madrid: Bosch.

Ray, José Domingo y Videla Escalada, Federico (1985) La frustración del contrato y la teoría de la causa. Buenos Aires: Abeledo-Perrot.

Ripert, Georges (1963) Tratado de Derecho Civil. Tomos IV y V. Buenos Aires: Editorial La Ley.

Ripert, Georges y Boulanger, Jean (1963) Tratado de Derecho Civil, según el Tratado de Planiol. Tomo IV. Volumen I. Traducción de Delia García Daireaux. Buenos Aires: La Ley.

Ruggiero, Roberto (Sin fecha) Instituciones de Derecho Civil. Tomo I. Cuarta Edición de la traducción española. Madrid: Instituto Editorial Reus.

Saborido Sánchez, Paloma (2005) La causa ilícita: Delimitación y efectos. Valencia: Tirant Monografías.

San Agustín de Hipona (1793) La Ciudad de Dios. Traducción del latín al castellano por Joseph Cayetano Díaz de Beyral y Bermúdez, Madrid: Imprenta Real. (2000) Las Confesiones. 2a Edición de Olegario García de la Fuente, Madrid: Ediciones Akal S. A.

Sánchez-Blanco, J. (1952) Onerosidad, gratuidad y causa. En Revista de Derecho Privado, Tomo XXXVI. Madrid.

Santo Tomás De Aquino (1990) III Suma Teológica. Prima Pars, Tratado de la Creación o Producción de todos los Seres por Dios, Q. 44, Sobre las criaturas en cuanto procedentes de Dios y sobre la primera causa de todos los seres, Introducción a las cuestiones 44 a 49 por José María Artola Barrenechea O.P., Madrid: Biblioteca de Autores Cristianos. 
SAVIGNI, Friedrich Karl. (1879) Sistema del derecho romano actual. Madrid: Góngora.

Scogmamiglio, Renato (1996) Teoría general del contrato. Traducción Fernando Hinestrosa, Colombia: Univesidad Externado de Colombia, Colombia.

Stiglitz, Rubén (1990) Contratos. Parte General. Buenos Aires: Editorial Depalma.

Supervielle, Bernardo (1952) Teoría de la causa. En Revista de la Facultad de Derecho, Tomo 2. Montevideo.

Taboada Córdova, Lizardo (1996) La causa del negocio jurídico. Lima: Editora y Distribuidora Jurídica Grijley E. I. R. L.

Torralva, Vicente (1966) Causa ilícita: exposición sistemática de la jurisprudencia del Tribual Supremo, en Anuario de Derecho Civil, Tomo XIX, Fascículo III, julio-septiembre, Madrid.

Traviesas, M. Miguel (1919) La causa en los negocios jurídicos. Madrid: Editorial Reus.

Videla Escalada, Federico (1968) La causa final en el Derecho Civil. Buenos Aires: Editorial Abeledo-Perrot.

Von Ihering, Rudolf (1960) El fin en el Derecho. Buenos Aires: Bibliográfica Omega.

Von Tunr, A. (1934) Tratado de la obligaciones. Tomo I. Primera Edición. Traducido del alemán y concordado por W. Roces. Madrid: Editorial Reus S. A.

Zannoni, Eduardo (1986) Ineficacia y nulidad de los actos jurídicos. Buenos Aires: Editorial Astrea.

ZimMERMANn, Reinhard (1990) The law of obligations roman foundation of civilian tradition, Juta \& Coo, Ltd.

Zumalacarregui, Tomás (1977) Causa y abstracción causal en el Derecho Civil español, Madrid.

\section{b) Obras nacionales}

Abeliuk Manasevich, René (1993) Las obligaciones. Tercera Edición. Santiago: Editorial Jurídica de Chile.

Alessandri Besa, Arturo (1949) La nulidad y la rescisión en el Derecho Civil chileno. Santiago: Imprenta Universitaria.

Alessandri Rodríguez, Arturo (1943) Responsabilidad Extracontractual en el Derecho Civil chileno. Santiago: Imprenta Universitaria.

(2004) Los contratos. Reimpresión $1^{\text {a }}$ Edición. Santiago: Editorial Jurídica de Chile.

(1931) La autocontratación o el acto jurídico consigo mismo. Santiago: Imprenta Cervantes.

Alessandri Rodríguez, Arturo y Somarriva Undurraga, Manuel (1991) Derecho Civil: Parte Preliminar y Parte General. Actualizado por Antonio Vodanovic H. Santiago: Ediar. 
(1998) Derecho Civil: Parte Preliminar y Parte General. Actualizado por Antonio Vodanovic H. Volumen II. Santiago: Editorial Jurídica de Chile.

Amunátegui Reyes, Miguel Luis (1885) Don Andrés Bello y el Código Civil. Santiago: Imprenta Cervantes.

(1894) Imperfecciones $i$ erratas manifiestas de la edición auténtica del Código Civil chileno. Santiago: Imprenta Cervantes.

Anguita, Ricardo (1912) Leyes promulgadas en Chile, desde 1810 hasta el 1 de junio de 1912. Santiago: Imprenta, Litografía i Encuadernación Barcelona.

Araya Jasma, Fernando (2006) La relación de causalidad en la responsabilidad civil. Fundación Fernando Fueyo Laneri. Santiago: LexisNexis.

Barcia Lehmann, Rodrigo (2007) Lecciones de Derecho Civil Chileno. Del acto jurídico, Tomo I. Santiago: Editorial Jurídica de Chile.

Barros Errázuriz, Alfredo (1932) Curso de Derecho Civil. Volumen III. Santiago: Editorial Nascimento.

Bello Bambach, Fernando (1930) La causa. Memoria de Prueba. Escuela de Derecho. Universidad de Chile. Santiago.

Bello López, Andrés (1930-1935). En Obras completas. Santiago: Editorial Nascimento.

Borja, Luis (1901) Estudios sobre el Código Civil chileno. Paris: A. Roger y F. Chernoviz Editores.

Claro Solar, Luis (1937) Explicaciones de Derecho Civil chileno y comparado. Tomo XI. Santiago: Imprenta Nascimiento.

Covarrubias, Álvaro y otros (1871) El Código Civil ante la Universidad o sus comentarios, Tomo I. Santiago: Imprenta Chilena.

CuQ, Edouard (1910) Las instituciones jurídicas de los romanos. Volumen III. Santiago: Imprenta El Debate.

Dávila, Óscar y Cañas, Rafael (1907) Esplicaciones de Código Civil (Clase de don Leopoldo Urrutia). Santiago: Imprenta Cervantes.

Dörr, Juan Carlos y otros (2005) La teoría de la imprevisión. En II curso de actualización jurídica. Teorías del Derecho Civil moderno. Santiago: Ediciones Universidad del Desarrollo.

Ducci Claro, Carlos (2007) Derecho Civil. Parte General. Cuarta Edición. Santiago: Editorial Jurídica de Chile.

Dupin, Emilio (1929) De la causa de las obligaciones. Memoria de Prueba. Escuela de Derecho. Santiago: Universidad de Chile.

Elizalde, Miguel (1971) Concordancias de los articulos del Código Civil chileno entre si $i$ con los artículos del Código francés. Santiago: Imprenta de la Libertad.

Figueroa VÁsquez, Waldo (1998) La acción de enriquecimiento sin causa. Fundación Fernando Fueyo Laneri. Santiago: Editorial ConoSur. 
Figueroa Yáñez, Gonzalo (1995) Curso de Derecho Civil. Tomo II. Teoría de los actos jurídicos. Tercera Edición. Santiago: Editorial Jurídica de Chile.

Guzmán Brito, Alejandro (1977) Para la historia de fijación acerca de los antecedentes sistemáticos y terminológicos de la parte general relativa a los actos y declaraciones de voluntad en el Código Civil chileno y en sus proyectos. En Revista de Estudios Histórico-Jurídicos 2, Valparaíso.

(2005) Acto, negocio, contrato y causa en la tradición del Derecho Europeo e iberoamericano. Primera edición. Navarra: Cizur Menor.

Hevia Calderón, Ricardo (1981) Concepto y función de la causa en el Código Civil chileno. Santiago: Editorial Jurídica de Chile.

León Hurtado, Avelino (1961) La causa. Colección de Estudios Jurídicos y Sociales. Número 49. Santiago: Editorial Jurídica de Chile.

Lira Urquieta, Pedro (1944) El Código Civil y el nuevo Derecho. Santiago: Imprenta Nascimento.

López DíAz, Patricia (2003) La Doctrina del levantamiento del velo y la instrumentalización de la personalidad jurídica. Primera Edición. Santiago: LexisNexis.

López Santa María, Jorge (1998) Los contratos. Parte general. Tomo II. Santiago: Editorial Jurídica de Chile.

Mera Molina, Jorge (1940) Exposición de la doctrina de la causa. Memoria de Prueba. Escuela de Derecho. Santiago: Universidad de Chile.

Morales, Jorge. (1937) En defensa del concepto de causa. En Revista de Derecho y Jurisprudencia. Tomo 34. Santiago.

Ortúzar Escobar, Enrique. (1938) De la inobservancia de la ley en relación con los actos jurídicos. Memoria de Prueba. Escuela de Derecho de la Universidad de Chile, Santiago.

Otero Espinoza, Franklin (1926) Concordancias y jurisprudencia del Código Civil chileno. Tomo I. Santiago: Casa Zamorano y Caperán Editora.

Peñailillo Arévalo, Daniel (2003) Obligaciones. Teoría General y Clasificaciones. La resolución por Incumplimiento. Primera Edición. Santiago: Editorial Jurídica de Chile.

Pescio Vargas, Victorio (1978) Manual de Derecho Civil. Volumen 2. Segunda Edición, Santiago: Editorial Jurídica de Chile.

Rioseco, Emilio (1958) La prueba ante la jurisprudencia. Santiago: Editorial Jurídica de Chile.

Rivera Restrepo, José y Urdangarín Mahn, Jaime (2011) La imitación desleal por aprovechamiento de la reputación y del esfuerzo ajeno. En Revista de la Facultad de Derecho de la Universidad Jesuita Alberto Hurtado, paper aceptado por el Consejo de Redacción, en imprenta. 
Rivera Restrepo, José (2010) De los aspectos generales en torno a la teoría de la causa. En Revista Ars Noni et Aequi, No 7, Segundo Semestre, Facultad de Derecho, Universidad Bernardo O'Higgins, agosto de 2010 .

(2011) De la causa en el Derecho comparado. En Revista del Magíster y Doctorado en Derecho, Escuela de Graduados, Facultad de Derecho, Universidad de Chile, No 4, en imprenta.

Ruz LÁrtiga, Gonzalo (2011) Explicaciones de Derecho Civil. Parte General y Acto Jurídico. Tomo I. Santiago: Editorial AbeledoPerrot, LegalPublishing Chile.

Schipani, S. (1981) Del derecho romano a las codificaciones latinoamericanas: la obra de Andrés Bello. Pluralidad de fuentes del título I del Libro IV del Código Civil de Chile y de sus proyectos. En Revista de Estudios Histórico-Jurídicos 6. Valparaíso.

Solar Ojeda, Washington (1963) Los actos juridicos abstractos. Memoria de Prueba. Escuela de Derecho. Santiago: Universidad de Chile.

Somarriva Undurraga, Manuel. (1984) Las obligaciones y los contratos ante la jurisprudencia. Santiago: Editorial Jurídica de Chile.

Tabolari Oliveros, Raúl (2010) Jurisprudencias esenciales, Derecho Civil, Tomo II, Cuasicontratos, Santiago: ISBN 978-956. de Chile.

(1943) Tratado de las Cauciones. Santiago: Editorial Jurídica

Velasco Letelier, Eugenio (1941) El objeto ante la jurisprudencia. Santiago: Editorial Nascimento.

Vial Del Río, Víctor (2003) Manual de Derecho de las obligaciones en el Código Civil chileno. Santiago: Editorial Biblioteca Americana.

(2003) Teoría general del acto juridico. Quinta Edición actualizada y aumentada. Santiago: Editorial Jurídica de Chile.

Vodanovic H., Antonio (1971) Curso de Derecho Civil. Basado en las explicaciones de Arturo Alessandri Rodríguez y Manuel Somarriva Undurraga. Tomo I. Santiago: Editorial Nascimento.

(2001) Manual de Derecho Civil. Segundo Volumen de las Partes Preliminar y General. Santiago: Editorial Jurídica ConoSur Ltda. 